Article

\title{
Profile of Environmental Chemicals in the Korean Population-Results of the Korean National Environmental Health Survey (KoNEHS) Cycle 3, 2015-2017
}

\author{
Sun Kyoung Jung ${ }^{1,2} \mathbb{D}$, Wookhee Choi ${ }^{3}$, Sung Yeon Kim ${ }^{1}$, Sooyeon Hong ${ }^{1}$, Hye Li Jeon ${ }^{1}$, Youngkyung Joo ${ }^{1}$,
} Chulwoo Lee ${ }^{1}$, Kyungho Choi ${ }^{4}$, Sungkyoon Kim ${ }^{4}\left(\mathbb{D}\right.$, Kee-Jae Lee ${ }^{5}$ (D) and Jiyoung Yoo ${ }^{1, *}$

1 Environmental Health Research Division, National Institute of Environmental Research, Ministry of Environment, Incheon 22689, Korea; sk0825@korea.kr (S.K.J.); harok2@korea.kr (S.Y.K.); suyeon83@korea.kr (S.H.); hyeli0922@korea.kr (H.L.J.); jooyk02@korea.kr (Y.J.); leecwoo@korea.kr (C.L.)

2 Graduate School of Urban Public Health, University of Seoul, Seoul 02504, Korea

3 Monitoring and Analysis Division, Wonju Regional Environmental Office, Ministry of Environment, Wonju 26461, Korea; whc405@korea.kr

4 Graduate School of Public Health, Seoul National University, Seoul 08826, Korea; kyungho@snu.ac.kr (K.C.); ddram2@snu.ac.kr (S.K.)

5 Department of Information Statistics and Data Science, College of Natural Science, Korea National Open University, Seoul 03087, Korea; kjlee@mail.knou.ac.kr

* Correspondence: yjy0216@korea.kr; Tel.: +82-32-560-7103

\section{check for} updates

Citation: Jung, S.K.; Choi, W.; Kim, S.Y.; Hong, S.; Jeon, H.L.; Joo, Y.; Lee, C.; Choi, K.; Kim, S.; Lee, K.-J.; et al. Profile of Environmental Chemicals in the Korean Population-Results of the Korean National Environmental Health Survey (KoNEHS) Cycle 3, 2015-2017. Int. J. Environ. Res. Public Health 2022, 19, 626. https://doi.org/ 10.3390/ijerph19020626

Academic Editor: Nicola Magnavita

Received: 19 November 2021

Accepted: 1 January 2022

Published: 6 January 2022

Publisher's Note: MDPI stays neutral with regard to jurisdictional claims in published maps and institutional affiliations.

Copyright: (C) 2022 by the authors. Licensee MDPI, Basel, Switzerland. This article is an open access article distributed under the terms and conditions of the Creative Commons Attribution (CC BY) license (https:// creativecommons.org/licenses/by/ $4.0 /)$.

\begin{abstract}
The Korean National Environmental Health Survey (KoNEHS) program provides useful information on chemical exposure, serves as the basis for environmental health policies, and suggests appropriate measures to protect public health. Initiated on a three-year cycle in 2009, it reports the concentrations of major environmental chemicals among the representative Korean population. KoNEHS Cycle 3 introduced children and adolescents into the analysis, where the blood and urine samples of 6167 participants were measured for major metals, phthalates, phenolics, and other organic compounds. Lead, mercury, cadmium, metabolites of DEHP and DnBP, and 3-phenoxybenzoic acid levels of the Korean adult population tended to decrease compared to previous survey cycles but remained higher than those observed in the US or Canada. Both bisphenol A (BPA) and trans,transmuconic acid concentrations have increased over time. Heavy metal concentrations (blood lead, and cadmium) in children and adolescents were approximately half that of adults, while some organic substances (e.g., phthalates and BPA) were high. BPA showed higher levels than in the US or Canada, whereas BPF and BPS showed lower detection rates in this cycle; however, as these are increasingly used as a substitute for BPA, further research is necessary. As environmental chemicals may affect childhood health and development, additional analyses should assess exposure sources and routes through continuous observations.
\end{abstract}

Keywords: children and adolescents; environmental chemicals; KoNEHS; national biomonitoring; temporal trend

\section{Introduction}

Human biomonitoring is an important tool for assessing internal exposure to environmental chemicals. Its history extends back to the 1890s, when exposure levels among occupational workers were measured in the workplace [1]. Since then, different studies have reported exposure to numerous substances through various pathways, outlining the utility of biomonitoring in environmental health management [2-5]. Indeed, several countries, including the United States, Canada, and Germany, have implemented national biomonitoring programs (NBPs) to inform the development of environmental health policies $[4,6,7]$. NBPs can generate exposure profiles of major environmental chemicals among 
representative populations, providing valuable information for prioritizing chemicals and policies $[3,6,8-10]$.

The Korean National Environmental Health Survey (KoNEHS) has been conducted in three-year cycles since its implementation in 2009. Three cycles have thus been conducted up to 2017, providing baseline information on major chemical exposure profiles. Cycles 1 and 2 were focused on the adult population $(n=12,789)$, measuring a total of 16 and 21 chemicals, respectively, including metals, bisphenol A (BPA), and metabolites of phthalates [11,12].

KoNEHS Cycle 3 (2015-2017) extended the population coverage to include children and adolescents. Many studies have reported that environmental chemicals are related to delayed growth and development in children and adolescents, who are particularly vulnerable to environmental pollution and related chronic diseases [11,13-16]. Accordingly, this importance was reflected in designing the KoNEHS Cycle 3, building upon the results of the Korean Environmental Exposure and Health Survey in Children and Adolescents (KorEHS-C) from 2012 to 2014 [17-19]. A total of 26 environmental chemicals were measured, including substances that became social issues such as parabens $[20,21]$ and bisphenol substitutes [22-24].

This study provides the updated exposure profiles for major environmental chemicals among the representative Korean population, thus helping to prioritize chemicals of concern that warrant further environmental health management efforts.

\section{Materials and Methods}

\subsection{Survey Design and Procedures}

To ensure representativeness of the adult population, the results of the 2010 Population and Housing Census (Statistics Korea) were used, and a stratified multi-stage sampling process was conducted. Through a household visit in the sampled survey district, participation was asked, and the survey was conducted with those who consented.

These sampling and field survey methods were the same as in Cycles 1 and 2 [11,12], the details of which can be found in Table 1.

Considering the participant accessibility and ease of sample collection, children and adolescents were extracted in units of kindergartens, childcare facilities, and educational institutions. Using households as sampling units enabled comprehensive sampling across a range of populations; however, children and adolescents who did not attend childcare or educational institutions may be omitted. However, the proportion of that those who attending such institutions was higher than $>90 \%$, which would be representative of the same age groups in Koreans [25].

Sampling institutions and sample sizes by age were selected based on the status of daycare centers and educational institutions published by the Ministry of Education and the Ministry of Health and Welfare The country was divided into five regions to be used as variables: Seoul, Gyeonggi/Incheon/Gangwon, Chungcheong, Honam/Jeju, and Yeongnam. In total, 127 schools and 56 kindergartens/childcare facilities were selected across all regions following the sampling process for the KorEHS-C [25].

This survey was approved by the Institutional Review Board of the National Institute of Environmental Research (NIER), Korea (NIER-2015-BR-006-01) and carried out only for those providing prior consent. 
Table 1. Survey sample design details of the KoNEHS Cycle 3 (2015-2017).

\begin{tabular}{|c|c|}
\hline & Method \\
\hline Survey design & Cross-sectional survey \\
\hline \multirow{3}{*}{ Target population } & Over 3 years (2015-2017) living in the Korea \\
\hline & Age $\geq 3$, male $/$ female \\
\hline & Housing Census (2010) \\
\hline \multirow{3}{*}{ Sampling unit } & List of nationwide kindergartens and daycares (2014) \\
\hline & List of elementary, middle, and high schools nationwide \\
\hline & Apartment and general enumeration district households \\
\hline \multirow[t]{2}{*}{ Target error } & $\pm 5 \%$ of the average value for each item \\
\hline & A minimum sample of $\geq 5500$ participants \\
\hline \multirow{8}{*}{ Sample size } & Infants $\geq 3$ years; $\sim 500$ (56 institutions) \\
\hline & Elementary, middle, and high school students; 1500 (127 schools) \\
\hline & $\begin{array}{c}\text { Adults } \geq 19 \text { years; } \sim 3500 \text { (233 survey districts) } \\
{[\text { Preschoolers] }}\end{array}$ \\
\hline & Multi-stage stratified cluster sampling \\
\hline & $\begin{array}{c}\text { Sampling of collection sites (5 areas), Regions (city or town) } \\
\text { stratifications }\end{array}$ \\
\hline & 1st sampling unit: Institutes (kindergarten and daycares) \\
\hline & : Age, sex group strata, random sampling \\
\hline & 2nd sampling unit: Individual \\
\hline \multirow{5}{*}{$\begin{array}{c}\text { Sampling frame } \\
\cdot \text { stratifications } \\
\cdot \text { characteristics } \\
\cdot \text { classification indicators } \\
\text { (dwelling and participant) }\end{array}$} & [School age children] \\
\hline & Multi-stage stratified cluster sampling \\
\hline & Sampling of collection sites (5 areas), Regions (city or town), and \\
\hline & school stratifications \\
\hline & 1st sampling unit: Institutes (schools) \\
\hline \multirow{9}{*}{ (dwelling and participant) } & : Age, sex group strata, random sampling \\
\hline & 2nd sampling unit: Individual (class and students) \\
\hline & [Adults] \\
\hline & Multi-stage stratified cluster sampling \\
\hline & 17 regions (city or town) stratifications \\
\hline & 1st sampling unit: Sampling district \\
\hline & 2nd sampling unit: Household \\
\hline & For region (city or town) stratifications: \\
\hline & Square root proportional distribution method \\
\hline \multirow[t]{3}{*}{ Sample allocation methods } & For detailed stratifications: \\
\hline & Proportional allocation method \\
\hline & Apply relative standard error after analysis \\
\hline
\end{tabular}

\subsection{Biological Sample Collection}

Through a field survey, $18 \mathrm{~mL}$ of blood and $60 \mathrm{~mL}$ of spot urine were collected from 6167 participants. We sent a message to each subjects notifying them of relevant information 2 days before the survey began. On the day of a field survey, we guided them to the location by mobile phone and finally requested their participation. For adults, samples were taken at the survey site. For preschoolers and children, urine samples were directly collected in a specimen cup at their homes on the day of survey. For adolescents, urine samples were similarly collected upon visiting a pre-negotiated hospital near the investigation.

In adults, 26 substances in their blood and urine were analyzed (Table 2), whereas in the cases of preschoolers and children, blood sample collections were difficult due to safety considerations, so 25 substances in urine (excepting lead) were analyzed. Mercury is a substance that is analyzed in both whole blood and urine, and the results of mercury in the urine of preschool children and children can be confirmed in Table 3. 
Table 2. Target chemicals of urinary analyses measured in KoNEHS Cycle 3 (2015-2017).

\begin{tabular}{|c|c|c|}
\hline Category & Chemicals & Analytical Technique \\
\hline \multirow{3}{*}{ Metals (3) } & Lead $^{\text {a }}$ & $\begin{array}{c}\text { GF-AAS, } \\
\text { (Analyst 800, PerkinElmer, } \\
\text { Waltham, MA, USA) }\end{array}$ \\
\hline & Mercury (total) ${ }^{a}$ & $\begin{array}{c}\text { DMA }^{\mathrm{b}} \\
\text { (DMA-80, Milestone, Shelton, } \\
\text { CT, USA) }\end{array}$ \\
\hline & Cadmium & $\begin{array}{c}\text { GF-AAS, } \\
\text { (240Z, Agilent, Santa Clara, } \\
\text { CA, USA) }\end{array}$ \\
\hline Phthalates metabolites (8) & $\begin{array}{c}\text { Mono-(2-ethyl-5-oxohexyl) } \\
\text { phthalate (MEOHP) } \\
\text { Mono-(2-ethyl-5-hydroxyhexyl) } \\
\text { phthalate (MEHHP) } \\
\text { Mono-(2-ethyl-5-carboxypentyl) } \\
\text { phthalate (MECPP) } \\
\text { Mono-n-butyl phthalate (MnBP) } \\
\text { Monobenzyl phthalate (MBzP) } \\
\text { Mono(3-carboxypropyl) phthalate } \\
\text { (MCPP) * } \\
\text { Mono-(carboxynonyl) phthalate } \\
\text { (MCNP) * } \\
\text { Mono-(carboxyoctyl) phthalate } \\
(\text { MCOP) * }\end{array}$ & $\begin{array}{c}\text { UPLC-MS/MS } \\
\text { (LCMS-8060, Shimadzu, } \\
\text { Kyoto, Japan) }\end{array}$ \\
\hline Environmental phenols (7) & $\begin{array}{l}\text { Bisphenol A } \\
\text { Bisphenol F* } \\
\text { Bisphenol S* } \\
\text { Triclosan } \\
\text { Ethyl paraben * } \\
\text { Methyl paraben * } \\
\text { Propyl paraben * }\end{array}$ & $\begin{array}{c}\text { UPLC-MS/MS } \\
\text { (LCMS-8060, Shimadzu, } \\
\text { Kyoto, Japan) }\end{array}$ \\
\hline $\begin{array}{l}\text { Pyrethroid pesticides } \\
\text { metabolite }(1)\end{array}$ & 3-phenoxybenzoic acid & $\begin{array}{c}\text { GC-MS } \\
\text { (Clarus 600T, Perkin Elmer, } \\
\text { Waltham, MA, USA) }\end{array}$ \\
\hline $\begin{array}{c}\text { Tobacco smoke } \\
\text { metabolite (1) }\end{array}$ & Cotinine & $\begin{array}{c}\text { GC-MS } \\
\text { (Clarus 680-SQ 8T, } \\
\text { PerkinElmer, Waltham, MA, } \\
\text { USA) }\end{array}$ \\
\hline PAHs metabolites (4) & $\begin{array}{c}\text { 1-Hydroxypyrene (1-OH-Pyr) } \\
\text { 2-Hydroxynaphthalene (2-NAP) } \\
\text { 1-Hydroxyphenanthrene } \\
\text { (1-OH-Phe) } \\
\text { 2-Hydroxyfluorene (2-OH-Flu) }\end{array}$ & $\begin{array}{c}\text { GC-MS } \\
\text { (7890A/5975C, Agilent, Santa } \\
\text { Clara, CA, USA) }\end{array}$ \\
\hline VOC metabolites (2) & $\begin{array}{c}\text { trans,trans-muconic acid } \\
\text { N-Acetyl-S-(benzyl)-L-cysteine * }\end{array}$ & $\begin{array}{c}\text { HPLC-MS/MS } \\
\text { (Agilent 6410B/1200, Agilent, } \\
\text { Santa Clara, CA, USA) }\end{array}$ \\
\hline
\end{tabular}


Table 3. Distribution of concentrations of environmental chemicals for the KoNEHS Cycle 3 (2015-2017). Units for all chemicals are in $\mu \mathrm{g} \cdot \mathrm{L}^{-1}$, except for lead, which is expressed as $\mu \mathrm{g} \cdot \mathrm{dL}^{-1}$.

\begin{tabular}{|c|c|c|c|c|c|c|c|c|c|c|}
\hline & Age & $\mathbf{N}$ & $\%<$ LOD & AM & GM & $\left(95 \% \mathrm{CI}^{\mathrm{a}}\right)$ & P25 & P50 & P75 & P95 \\
\hline \multicolumn{11}{|l|}{ Whole Blood } \\
\hline \multicolumn{11}{|l|}{ Metals } \\
\hline \multirow{2}{*}{ Lead $\left(\mathrm{ug} \cdot \mathrm{dL}^{-1}\right)$} & $12-18$ & 912 & 2.74 & 0.883 & 0.802 & $(0.754,0.853)$ & 0.611 & 0.834 & 1.10 & 1.52 \\
\hline & $\geq 19$ & 3747 & 0.1 & 1.79 & 1.60 & $(1.56,1.65)$ & 1.20 & 1.60 & 2.20 & 3.36 \\
\hline \multirow[t]{2}{*}{ Mercury (total) } & $12-18$ & 912 & 0 & 1.56 & 1.37 & $(1.30,1.43)$ & 1.00 & 1.35 & 1.84 & 3.02 \\
\hline & $\geq 19$ & 3745 & 0 & 3.50 & 2.75 & $(2.63,2.88)$ & 1.75 & 2.71 & 4.15 & 8.81 \\
\hline \multicolumn{11}{|l|}{ Spot Urine } \\
\hline \multicolumn{11}{|l|}{ Metals } \\
\hline \multirow[t]{4}{*}{ Mercury (total) } & $3-5$ & 571 & 2.10 & 0.565 & 0.422 & $(0.371,0.479)$ & 0.257 & 0.396 & 0.693 & 1.30 \\
\hline & $6-11$ & 887 & 1.24 & 0.581 & 0.394 & $(0.370,0.418)$ & 0.267 & 0.373 & 0.562 & 1.09 \\
\hline & $12-18$ & 906 & 3.31 & 0.577 & 0.413 & $(0.374,0.457)$ & 0.246 & 0.421 & 0.680 & 1.39 \\
\hline & $\geq 19$ & 3780 & 6.1 & 0.518 & 0.355 & $(0.335,0.376)$ & 0.196 & 0.339 & 0.616 & 1.42 \\
\hline \multirow[t]{4}{*}{ Cadmium } & $3-5$ & 571 & 18.7 & 0.160 & 0.108 & $(0.086,0.136)$ & 0.057 & 0.091 & 0.206 & 0.430 \\
\hline & $6-11$ & 887 & 1.92 & 0.298 & 0.232 & $(0.212,0.255)$ & 0.146 & 0.231 & 0.354 & 0.735 \\
\hline & $12-18$ & 906 & 1.99 & 0.377 & 0.289 & $(0.264,0.316)$ & 0.182 & 0.297 & 0.445 & 0.951 \\
\hline & $\geq 19$ & 3781 & 6.8 & 0.615 & 0.359 & $(0.326,0.395)$ & 0.185 & 0.422 & 0.811 & 1.75 \\
\hline \multicolumn{11}{|c|}{ Phthalates metabolites } \\
\hline \multirow[t]{4}{*}{ MEHHP } & $3-5$ & 571 & 0 & 45.9 & 34.6 & $(31.3,38.2)$ & 21.3 & 36.2 & 58.7 & 96.8 \\
\hline & $6-11$ & 885 & 0 & 37.5 & 28.8 & $(26.5,31.2)$ & 18.7 & 29.6 & 47.2 & 85.3 \\
\hline & $12-18$ & 901 & 0.11 & 19.9 & 13.6 & $(12.0,15.5)$ & 8.39 & 14.8 & 24.6 & 53.6 \\
\hline & $\geq 19$ & 3781 & 0.4 & 23.1 & 13.2 & $(12.0,14.4)$ & 6.89 & 13.7 & 25.9 & 62.6 \\
\hline \multirow[t]{4}{*}{ MEOHP } & $\overline{3}-5$ & 571 & 0 & 34.3 & 25.5 & $(23.0,28.3)$ & 15.2 & 26.2 & 40.9 & 83.6 \\
\hline & $6-11$ & 885 & 0 & 25.7 & 19.2 & $(17.6,20.9)$ & 11.8 & 19.5 & 31.6 & 65.3 \\
\hline & $12-18$ & 901 & 0.22 & 14.1 & 9.24 & $(8.02,10.7)$ & 5.10 & 10.3 & 17.1 & 38.5 \\
\hline & $\geq 19$ & 3781 & 0.5 & 18.1 & 9.88 & $(8.89,11.0)$ & 5.03 & 10.7 & 20.8 & 50.9 \\
\hline \multirow[t]{4}{*}{ МЕСРP } & $\overline{3}-5$ & 571 & 0 & 65.9 & 45.3 & $(38.4,53.5)$ & 25.6 & 46.7 & 80.9 & 173 \\
\hline & $6-11$ & 885 & 0 & 59.0 & 44.5 & $(40.9,48.5)$ & 27.2 & 44.0 & 72.6 & 144 \\
\hline & $12-18$ & 901 & 0 & 36.8 & 28.4 & $(25.3,31.8)$ & 18.0 & 28.5 & 45.7 & 89.7 \\
\hline & $\geq 19$ & 3781 & 0 & 40.3 & 23.2 & $(20.8,25.7)$ & 11.4 & 21.7 & 44.0 & 131 \\
\hline \multirow{4}{*}{ MnBP } & $3-5$ & 571 & 0.53 & 79.8 & 47.2 & $(40.8,54.6)$ & 32.2 & 52.9 & 79.1 & 157 \\
\hline & $6-11$ & 885 & 0 & 55.9 & 43.2 & $(40.6,46.1)$ & 28.3 & 45.1 & 68.8 & 126 \\
\hline & $12-18$ & 897 & 0.11 & 60.6 & 36.9 & $(29.6,46.0)$ & 18.6 & 36.5 & 76.8 & 168 \\
\hline & $\geq 19$ & 3779 & 1.1 & 45.6 & 22.3 & $(19.2,25.8)$ & 12.5 & 25.3 & 52.0 & 125 \\
\hline \multirow[t]{4}{*}{$\mathrm{MBzP}$} & $3-5$ & 571 & 3.68 & 8.06 & 3.12 & $(2.65,3.69)$ & 1.62 & 3.21 & 6.83 & 22.0 \\
\hline & 6-11 & 885 & 5.99 & 6.85 & 2.80 & $(2.34,3.35)$ & 1.35 & 3.17 & 7.02 & 24.2 \\
\hline & $12-18$ & 901 & 3.77 & 6.91 & 2.78 & $(2.36,3.27)$ & 1.19 & 2.97 & 6.90 & 25.3 \\
\hline & $\geq 19$ & 3781 & 2.0 & 4.40 & 1.99 & $(1.80,2.20)$ & 0.932 & 2.05 & 4.30 & 14.6 \\
\hline \multirow[t]{4}{*}{ MCNP } & $\overline{3}-5$ & 571 & 4.90 & 0.670 & 0.491 & $(0.425,0.568)$ & 0.316 & 0.464 & 0.685 & 1.83 \\
\hline & $6-11$ & 885 & 2.26 & 0.661 & 0.533 & $(0.505,0.562)$ & 0.408 & 0.526 & 0.674 & 1.45 \\
\hline & $12-18$ & 901 & 3.11 & 0.535 & 0.452 & $(0.423,0.483)$ & 0.331 & 0.499 & 0.594 & 1.02 \\
\hline & $\geq 19$ & 3781 & 10.5 & 0.613 & 0.441 & $(0.395,0.493)$ & 0.228 & 0.502 & 0.774 & 1.47 \\
\hline \multirow[t]{4}{*}{ MCOP } & $\overline{3}-5$ & 571 & 0 & 2.27 & 1.62 & $(1.43,1.83)$ & 0.894 & 1.55 & 2.66 & 6.76 \\
\hline & $6-11$ & 885 & 0.11 & 3.38 & 2.24 & $(2.07,2.42)$ & 1.28 & 2.13 & 3.79 & 8.31 \\
\hline & $12-18$ & 901 & 1.89 & 2.41 & 1.71 & $(1.55,1.88)$ & 1.07 & 1.73 & 2.94 & 6.83 \\
\hline & $\geq 19$ & 3781 & 0.6 & 1.74 & 1.07 & $(0.968,1.19)$ & 0.569 & 1.06 & 1.95 & 4.59 \\
\hline \multirow[t]{4}{*}{ МСРP } & $3-5$ & 571 & 0.18 & 2.28 & 1.80 & $(1.63,1.99)$ & 1.25 & 1.70 & 2.57 & 5.30 \\
\hline & $6-11$ & 885 & 0.45 & 1.97 & 1.56 & $(1.49,1.64)$ & 1.07 & 1.45 & 2.08 & 4.43 \\
\hline & $12-18$ & 901 & 0.22 & 1.75 & 1.48 & $(1.35,1.62)$ & 1.03 & 1.38 & 2.09 & 3.89 \\
\hline & $\geq 19$ & 3781 & 0.6 & 1.63 & 1.13 & $(1.02,1.25)$ & 0.672 & 0.997 & 2.02 & 3.84 \\
\hline
\end{tabular}


Table 3. Cont.

\begin{tabular}{|c|c|c|c|c|c|c|c|c|c|c|}
\hline & Age & $\mathbf{N}$ & $\%<$ LOD & AM & GM & $\left(95 \% \mathrm{CI}^{\mathrm{a}}\right)$ & P25 & P50 & P75 & P95 \\
\hline \multicolumn{11}{|c|}{ Environmental phenols } \\
\hline \multirow[t]{4}{*}{ Bisphenol A } & $3-5$ & 571 & 1.23 & 4.33 & 2.41 & $(2.05,2.83)$ & 1.43 & 2.60 & 4.39 & 10.6 \\
\hline & $6-11$ & 887 & 3.95 & 3.22 & 1.70 & $(1.49,1.95)$ & 0.849 & 1.98 & 3.59 & 10.1 \\
\hline & $12-18$ & 904 & 3.10 & 2.65 & 1.39 & $(1.20,1.61)$ & 0.755 & 1.45 & 2.84 & 9.13 \\
\hline & $\geq 19$ & 3780 & 2.1 & 2.51 & 1.18 & $(1.06,1.32)$ & 0.517 & 1.32 & 2.76 & 7.78 \\
\hline \multirow[t]{4}{*}{ Bisphenol F } & $3-5$ & 571 & 69.9 & $*$ & $*$ & $*$ & $<\mathrm{LOD}$ & $<$ LOD & 0.093 & 0.761 \\
\hline & $6-11$ & 884 & 65.3 & * & * & * & $<\mathrm{LOD}$ & $<\mathrm{LOD}$ & 0.132 & 1.20 \\
\hline & $12-18$ & 900 & 56.0 & $*$ & $*$ & $*$ & $<\mathrm{LOD}$ & $<$ LOD & 0.153 & 1.48 \\
\hline & $\geq 19$ & 3777 & 59.3 & * & $*$ & * & $<\mathrm{LOD}$ & $<\mathrm{LOD}$ & 0.141 & 1.23 \\
\hline \multirow{4}{*}{ Bisphenol S } & $3-5$ & 571 & 47.5 & * & * & * & $<\mathrm{LOD}$ & 0.020 & 0.046 & 0.186 \\
\hline & $6-11$ & 884 & 46.0 & $*$ & $*$ & $*$ & $<\mathrm{LOD}$ & 0.023 & 0.065 & 0.523 \\
\hline & $12-18$ & 900 & 38.2 & 0.293 & 0.053 & $(0.041,0.068)$ & $<\mathrm{LOD}$ & 0.036 & 0.120 & 1.08 \\
\hline & $\geq 19$ & 3776 & 45.7 & $*$ & $*$ & $*$ & $<\mathrm{LOD}$ & 0.022 & 0.057 & 0.288 \\
\hline \multirow[t]{4}{*}{ Triclosan } & $3-5$ & 571 & 21.9 & 1.57 & 0.513 & $(0.435,0.606)$ & 0.208 & 0.400 & 1.02 & 4.79 \\
\hline & $6-11$ & 887 & 32.6 & 3.52 & 0.452 & $(0.404,0.507)$ & $<\mathrm{LOD}$ & 0.316 & 0.828 & 6.05 \\
\hline & $12-18$ & 904 & 35.3 & 3.96 & 0.420 & $(0.369,0.479)$ & $<\mathrm{LOD}$ & 0.315 & 0.714 & 4.75 \\
\hline & $\geq 19$ & 3780 & 50.9 & $*$ & $*$ & * & $<\mathrm{LOD}$ & $<\mathrm{LOD}$ & 0.538 & 5.39 \\
\hline \multirow[t]{4}{*}{ Methyl Paraben } & $3-5$ & 571 & 0 & 646 & 46.3 & $(37.1,57.8)$ & 8.81 & 25.8 & 150 & 3445 \\
\hline & $6-11$ & 884 & 0 & 188 & 28.9 & $(24.6,33.9)$ & 7.16 & 18.8 & 91.3 & 913 \\
\hline & $12-18$ & 900 & 0 & 107 & 26.1 & $(21.9,31.2)$ & 7.17 & 18.2 & 91.5 & 510 \\
\hline & $\geq 19$ & 3779 & 0 & 128 & 35.2 & $(32.0,38.6)$ & 9.26 & 34.6 & 126 & 506 \\
\hline \multirow[t]{4}{*}{ Ethyl Paraben } & $3-5$ & 571 & 1.05 & 106 & 14.2 & $(10.5,19.1)$ & 2.66 & 17.2 & 66.2 & 526 \\
\hline & $6-11$ & 884 & 1.13 & 122 & 11.4 & $(8.56,15.3)$ & 1.96 & 10.6 & 69.0 & 504 \\
\hline & $12-18$ & 900 & 0.44 & 85.6 & 19.1 & $(14.0,26.2)$ & 4.88 & 19.0 & 71.6 & 350 \\
\hline & $\geq 19$ & 3779 & 1.0 & 158 & 30.9 & $(27.1,35.2)$ & 7.82 & 36.2 & 139 & 676 \\
\hline \multirow[t]{4}{*}{ Propyl Paraben } & $3-5$ & 571 & 0.70 & 153 & 4.36 & $(3.29,5.80)$ & 0.664 & 2.48 & 18.0 & 699 \\
\hline & $6-11$ & 884 & 5.43 & 30.7 & 1.83 & $(1.52,2.21)$ & 0.346 & 1.37 & 7.15 & 104 \\
\hline & $12-18$ & 900 & 2.11 & 38.7 & 3.19 & $(2.55,3.98)$ & 0.796 & 2.11 & 10.8 & 212 \\
\hline & $\geq 19$ & 3778 & 3.9 & 51.0 & 3.07 & $(2.73,3.46)$ & 0.464 & 2.12 & 16.9 & 224 \\
\hline \multicolumn{11}{|c|}{ Pyrethroid pesticides metabolites } \\
\hline \multirow[t]{4}{*}{ 3-PBA } & $3-5$ & 570 & 0.35 & 2.24 & 1.08 & $(0.870,1.33)$ & 0.536 & 0.970 & 1.86 & 9.34 \\
\hline & $6-11$ & 887 & 0.68 & 2.40 & 1.36 & $(1.21,1.52)$ & 0.749 & 1.29 & 2.39 & 7.44 \\
\hline & $12-18$ & 904 & 1.66 & 2.03 & 1.02 & $(0.842,1.24)$ & 0.565 & 1.12 & 2.18 & 5.93 \\
\hline & $\geq 19$ & 3772 & 0.9 & 1.82 & 0.965 & $(0.887,1.05)$ & 0.499 & 1.03 & 2.05 & 6.09 \\
\hline \multicolumn{11}{|c|}{ Environmental tobacco smoke metabolites } \\
\hline \multirow[t]{4}{*}{ Cotinine } & $3-5$ & 571 & 20.5 & 1.69 & 1.05 & $(0.913,1.20)$ & 0.450 & 1.19 & 2.29 & 4.80 \\
\hline & $6-11$ & 887 & 18.9 & 2.12 & 1.20 & $(1.05,1.38)$ & 0.521 & 1.48 & 2.82 & 5.84 \\
\hline & $12-18$ & 904 & 7.19 & 36.1 & 3.04 & $(2.50,3.70)$ & 1.40 & 2.79 & 4.72 & 85.2 \\
\hline & $\geq 19$ & 3784 & 6.7 & 240 & 5.59 & $(4.80,6.50)$ & 0.799 & 1.80 & 12.7 & 1530 \\
\hline \multirow{2}{*}{19 years and older } & None & 3181 & 84.0 & 39.6 & 1.87 & $(1.65,2.12)$ & 0.698 & 1.30 & 3.10 & 75.6 \\
\hline & Smoker & 603 & 16.0 & 1071 & 524 & $(393,700)$ & 429 & 1008 & 1504 & 2575 \\
\hline
\end{tabular}


Table 3. Cont.

\begin{tabular}{|c|c|c|c|c|c|c|c|c|c|c|}
\hline & Age & $\mathbf{N}$ & $\%<$ LOD & AM & GM & $\left(95 \% \mathrm{CI}^{\mathrm{a}}\right)$ & P25 & P50 & P75 & P95 \\
\hline \multicolumn{11}{|c|}{ PAHs metabolites } \\
\hline \multirow[t]{4}{*}{ 1-OH-Pyr } & $3-5$ & 554 & 47.5 & $*$ & $*$ & $*$ & $<\mathrm{LOD}$ & 0.080 & 0.353 & 1.02 \\
\hline & $6-11$ & 864 & 34.4 & 0.319 & 0.108 & $(0.091,0.127)$ & $<\mathrm{LOD}$ & 0.208 & 0.442 & 1.02 \\
\hline & $12-18$ & 867 & 31.5 & 0.613 & 0.163 & $(0.115,0.230)$ & $<\mathrm{LOD}$ & 0.338 & 0.804 & 2.21 \\
\hline & $\geq 19$ & 3754 & 28.4 & 0.364 & 0.130 & $(0.118,0.143)$ & $<\mathrm{LOD}$ & 0.201 & 0.434 & 1.28 \\
\hline \multirow[t]{4}{*}{ 2-NAP } & $3-5$ & 554 & 1.26 & 6.30 & 3.37 & $(2.89,3.92)$ & 1.64 & 3.31 & 7.16 & 21.3 \\
\hline & $6-11$ & 864 & 3.82 & 5.63 & 2.67 & $(2.37,3.01)$ & 1.45 & 2.71 & 5.16 & 19.8 \\
\hline & $12-18$ & 866 & 2.77 & 6.29 & 3.05 & $(2.63,3.53)$ & 1.69 & 3.15 & 6.40 & 20.2 \\
\hline & $\geq 19$ & 3754 & 1.3 & 5.59 & 2.63 & $(2.48,2.79)$ & 1.23 & 2.42 & 6.16 & 21.0 \\
\hline \multirow[t]{4}{*}{ 1-OH-Phe } & $3-5$ & 554 & 38.3 & 0.156 & 0.080 & $(0.069,0.093)$ & $<\mathrm{LOD}$ & 0.054 & 0.194 & 0.499 \\
\hline & $6-11$ & 864 & 41.8 & * & * & $*$ & $<\mathrm{LOD}$ & 0.168 & 0.360 & 0.933 \\
\hline & $12-18$ & 866 & 38.2 & 0.265 & 0.127 & $(0.107,0.151)$ & $<\mathrm{LOD}$ & 0.158 & 0.367 & 0.822 \\
\hline & $\geq 19$ & 3751 & 32.5 & 0.269 & 0.117 & $(0.109,0.126)$ & $<\mathrm{LOD}$ & 0.135 & 0.303 & 0.779 \\
\hline \multirow[t]{4}{*}{ 2-OH-Flu } & $3-5$ & 549 & 19.7 & 2.18 & 0.495 & $(0.327,0.750)$ & 0.133 & 0.589 & 1.98 & 10.7 \\
\hline & $6-11$ & 864 & 20.0 & 0.380 & 0.209 & $(0.178,0.246)$ & 0.085 & 0.279 & 0.513 & 1.08 \\
\hline & $12-18$ & 867 & 15.9 & 0.485 & 0.263 & $(0.225,0.307)$ & 0.145 & 0.317 & 0.647 & 1.40 \\
\hline & $\geq 19$ & 3754 & 14.1 & 0.697 & 0.321 & $(0.295,0.349)$ & 0.159 & 0.379 & 0.780 & 2.58 \\
\hline \multicolumn{11}{|c|}{ VOCs metabolites } \\
\hline \multirow[t]{4}{*}{ t,t-MA } & $3-5$ & 571 & 0 & 133 & 82.2 & $(71.9,94.1)$ & 41.7 & 73.2 & 148 & 470 \\
\hline & $6-11$ & 887 & 0.56 & 161 & 91.2 & $(81.9,101)$ & 45.9 & 86.1 & 177 & 457 \\
\hline & $12-18$ & 904 & 0.66 & 147 & 80.4 & $(68.1,95.0)$ & 42.6 & 82.9 & 156 & 441 \\
\hline & $\geq 19$ & 3777 & 0.4 & 162 & 86.2 & $(80.7,92.0)$ & 41.4 & 88.5 & 185 & 498 \\
\hline \multirow[t]{4}{*}{ BMA } & $3-5$ & 571 & 0 & 26.9 & 10.6 & $(9.31,12.2)$ & 5.58 & 9.27 & 17.6 & 120 \\
\hline & $6-11$ & 883 & 0 & 13.1 & 7.39 & $(6.69,8.16)$ & 4.08 & 6.90 & 11.6 & 36.7 \\
\hline & $12-18$ & 899 & 0.33 & 9.09 & 5.66 & $(5.00,6.40)$ & 3.29 & 6.04 & 9.71 & 27.1 \\
\hline & $\geq 19$ & 3777 & 0.4 & 11.8 & 4.63 & $(4.28,5.02)$ & 2.42 & 4.74 & 8.95 & 27.9 \\
\hline
\end{tabular}

a $95 \%$ confidence interval of the GM; GM, geometric mean; * $40 \%$ of samples were below the LOD, so the percentile distribution was reported, but GM was not calculated; LOD, limit of detection; AM, arithmetic mean.

\subsection{Questionnaire}

Questionnaire items were continuous with Cycles 1 and 2, focusing on demographic and socioeconomic characteristics, living environments, recent diet, and lifestyle to identify exposure factors and routes of environmental chemicals.

A single household member representing preschoolers and elementary school students completed both the household and individual questionnaire surveys. Completed questionnaires were submitted to kindergartens, childcare facilities, and schools to be collected later. For middle and high school students, one household member representing a student completed the common household questionnaire, and individual questions were conducted face-to-face by a trained interviewer. For adults, survey questionnaires were completed solely through face-to-face interviews.

\subsection{Environmental Chemical Analysis and Quality Assurance/Control}

The biological samples collected in the field survey were transported under cold conditions $\left(2-6{ }^{\circ} \mathrm{C}\right)$, with temperatures checked using a temperature logger (TR52-S temperature data logger, ThermoFisher). The samples were aliquoted from the center within $24 \mathrm{~h}$, and kept frozen at $-20{ }^{\circ} \mathrm{C}$ until analysis. All processes were performed according to the "Biological sample management guidelines of the KoNEHS Cycle 3 [26]".

Of the 26 target chemicals selected (Table 2), nine were added compared to the KoNEHS Cycle 2, including endocrine disrupting chemicals and substances expected to increase exposure due to increased usage: mono(3-carboxypropyl) phthalate (MCPP), mono(carboxynonyl) phthalate (MCNP), mono-(carboxyoctyl) phthalate (MCOP), bisphenol F, bisphenol S, methyl-paraben, ethyl-paraben, propyl-paraben, and N-Acetyl-S-(benzyl)-Lcysteine. 
The target chemicals were analyzed according to the "Analysis manual of the KoNEHS Cycle 3" [27,28], and the equipment used for each chemical analysis are listed in Table 2. The analytical laboratories participated in external quality control programs (e.g., G-EQUAS in Germany, and proficiency testing by NIER) twice a year, and periodic quality assurance/quality control (e.g., linearity and slope of the calibration curve, detection limit, accuracy, and precision) measurements were performed. Table S1 summarizes the analytical methods and limits of detection (LOD) for target chemicals.

\subsection{Statistical Analyses}

Measured values were log-transformed and analyzed using the survey means procedure, after accounting for stratification variables and survey sample weight. Measurements below the LOD were assigned a value equal to LOD $/ \sqrt{ } 2$ for the calculation of geometric means $[6,29]$. When non-detects were $\geq 40 \%$, the arithmetic and geometric means were not calculated. Statistical significance was confirmed with a P value of less than 0.05 . SAS software (9.4; SAS Institute Inc., Cary, NC, USA) was used for all statistical analyses.

\section{Results}

\subsection{Participant Characteristics}

The study population consisted of preschoolers (3-5 years, $\mathrm{N}=571$ ), children (6-11 years, $\mathrm{N}=887$ ), adolescents (12-18 years, $\mathrm{N}=922)$, and adults ( $\geq 19$ years; $\mathrm{N}=3787$ ), for a total of participants of 6167 (2815 males and 3352 females). Within the adults, the proportion of older subjects $>50$ years was high, especially higher number of females present among participants $>50$ years as well. Many more female adult contacts than young people or elderly male for academic or work reasons were made when visiting households for recruitment. Furthermore, the voluntary participation rate was higher for women than men.

Children and adolescents were recruited through educational institutions; the gender ratios of the final participants were maintained by adjusting for age and gender when recruiting.

\subsection{Metals}

The geometric mean (GM) concentration of blood lead in adolescents $\left(0.802 \mu \mathrm{g} \cdot \mathrm{dL}^{-1}\right)$ were approximately half those of adults $\left(1.60 \mu \mathrm{g} \cdot \mathrm{dL}^{-1}\right.$; Table 3$)$, as were those of blood mercury $\left(1.37 \mu \mathrm{g} \cdot \mathrm{L}^{-1}\right.$ and $2.75 \mu \mathrm{g} \cdot \mathrm{L}^{-1}$, respectively; Table 3$)$. The GM concentrations of urinary mercury in preschoolers, children, adolescents, and adults were $0.422 \mu \mathrm{g} \cdot \mathrm{L}^{-1}, 0.394 \mu \mathrm{g} \cdot \mathrm{L}^{-1}$, $0.413 \mu \mathrm{g} \cdot \mathrm{L}^{-1}$, and $0.355 \mu \mathrm{g} \cdot \mathrm{L}^{-1}$, respectively (Table 3); whereas those of urinary cadmium were $0.108 \mu \mathrm{g} \cdot \mathrm{L}^{-1}, 0.232 \mu \mathrm{g} \cdot \mathrm{L}^{-1}, 0.289 \mu \mathrm{g} \cdot \mathrm{L}^{-1}$ and $0.359 \mu \mathrm{g} \cdot \mathrm{L}^{-1}$, respectively (Table 3).

\subsection{Phthalates Metabolites, BPA, and Triclosan (TCS)}

The GM concentration in preschoolers, children, and adolescents were mono(2-ethyl-5hydroxyhexyl) phthalate (MEHHP): $34.6 \mu \mathrm{g} \cdot \mathrm{L}^{-1}, 28.8 \mu \mathrm{g} \cdot \mathrm{L}^{-1}$, and $13.6 \mu \mathrm{g} \cdot \mathrm{L}^{-1}$; Mono (2-ethyl-5-oxohexyl) phthalate (MEOHP): $25.5 \mu \mathrm{g} \cdot \mathrm{L}^{-1}, 19.2 \mu \mathrm{g} \cdot \mathrm{L}^{-1}$, and $9.24 \mu \mathrm{g} \cdot \mathrm{L}^{-1}$; and Mono(2-ethyl-5-hydroxyhexyl) phthalate (MECPP): $45.3 \mu \mathrm{g} \cdot \mathrm{L}^{-1}, 44.5 \mu \mathrm{g} \cdot \mathrm{L}^{-1}$, and $28.4 \mu \mathrm{g} \cdot \mathrm{L}^{-1}$, respectively. Accordingly, phthalate metabolite concentrations in preschoolers were approximately $2-3$ times higher than those of adults: $\mathrm{MEHHP}, 13.2 \mu \mathrm{g} \cdot \mathrm{L}^{-1}$; MEOHP, $9.88 \mu \mathrm{g} \cdot \mathrm{L}^{-1}$; MECPP, $23.2 \mu \mathrm{g} \cdot \mathrm{L}^{-1}$. For MCNP, MCOP, and MCPP added in Cycle 3, the GM concentrations were similar in preschoolers, children, adolescents, and adults: MCNP: 0.491 $\mu \mathrm{g} \cdot \mathrm{L}^{-1}, 0.533 \mu \mathrm{g} \cdot \mathrm{L}^{-1}, 0.452 \mu \mathrm{g} \cdot \mathrm{L}^{-1}$, and $0.441 \mu \mathrm{g} \cdot \mathrm{L}^{-1} ; \mathrm{MCOP}: 1.62 \mu \mathrm{g} \cdot \mathrm{L}^{-1}, 2.24 \mu \mathrm{g} \cdot \mathrm{L}^{-1}$, $1.71 \mu \mathrm{g} \cdot \mathrm{L}^{-1}$, and $1.07 \mu \mathrm{g} \cdot \mathrm{L}^{-1}$; and MCPP: $1.80 \mu \mathrm{g} \cdot \mathrm{L}^{-1}, 1.56 \mu \mathrm{g} \cdot \mathrm{L}^{-1}, 1.48 \mu \mathrm{g} \cdot \mathrm{L}^{-1}$, and $1.13 \mu \mathrm{g} \cdot \mathrm{L}^{-1}$, respectively (Table 3 ).

The GM concentrations of urinary BPA decreased with age: $2.41 \mu \mathrm{g} \cdot \mathrm{L}^{-1}, 1.70 \mu \mathrm{g} \cdot \mathrm{L}^{-1}$, $1.39 \mu \mathrm{g} \cdot \mathrm{L}^{-1}$, and $1.18 \mu \mathrm{g} \cdot \mathrm{L}^{-1}$ in preschoolers, children, adolescents, and adults, respectively (Table 3). The GM concentrations of urinary TCS in preschoolers, children, and adolescents were $0.513 \mu \mathrm{g} \cdot \mathrm{L}^{-1}, 0.452 \mu \mathrm{g} \cdot \mathrm{L}^{-1}$, and $0.420 \mu \mathrm{g} \cdot \mathrm{L}^{-1}$, respectively (Table 3 ). 


\subsection{Parabens}

The GM concentrations of methyl- and propyl parabens were relatively high in preschoolers $\left(46.3 \mu \mathrm{g} \cdot \mathrm{L}^{-1}\right.$ and $4.36 \mu \mathrm{g} \cdot \mathrm{L}^{-1}$, respectively). Notably, the 95th percentile of urinary methyl paraben in preschoolers was $3445 \mu \mathrm{g} \cdot \mathrm{L}^{-1}, \leq 10$ times higher than those of other age groups. The preschooler concentrations of propyl paraben showed a similar pattern, with a 95th percentile of $699 \mu \mathrm{g} \cdot \mathrm{L}^{-1}, \leq 6$ times greater than other age group populations. The GM concentrations of urinary ethyl paraben in preschoolers, children, and adolescents were $14.2 \mu \mathrm{g} \cdot \mathrm{L}^{-1}, 11.4 \mu \mathrm{g} \cdot \mathrm{L}^{-1}, 19.1 \mu \mathrm{g} \cdot \mathrm{L}^{-1}$, respectively (Table 3).

\subsection{3-PBA and Cotinine}

Children maintained slightly higher GM concentrations of urinary 3-phenoxybenzoic acid (3-PBA): $1.08 \mu \mathrm{g} \cdot \mathrm{L}^{-1}, 1.36 \mu \mathrm{g} \cdot \mathrm{L}^{-1}, 1.02 \mu \mathrm{g} \cdot \mathrm{L}^{-1}$, and $0.965 \mu \mathrm{g} \cdot \mathrm{L}^{-1}$ (Table 3) for preschoolers, children, adolescents, and adults, respectively.

The GM concentrations of urinary cotinine in adolescents were significantly higher than for preschoolers and children: $1.05 \mu \mathrm{g} \cdot \mathrm{L}^{-1}, 1.20 \mu \mathrm{g} \cdot \mathrm{L}^{-1}, 3.04 \mu \mathrm{g} \cdot \mathrm{L}^{-1}$, and $5.59 \mu \mathrm{g} \cdot \mathrm{L}^{-1}$ for preschoolers, children, adolescents, and adults, respectively (Table 3). For adults, the cotinine concentrations of smokers $\left(524 \mu \mathrm{g} \cdot \mathrm{L}^{-1}\right)$ was significantly higher than that of non-smokers $\left(1.87 \mu \mathrm{g} \cdot \mathrm{L}^{-1}\right)$.

\subsection{Polycyclic Aromatic Hydrocarbon (PAH) and Volatile Organic Compound (VOC) Metabolites}

The GM concentration of urinary 1-hydroxypyrene (1-OH-Pyr) in children, adolescents, and adults was $0.108 \mu \mathrm{g} \cdot \mathrm{L}^{-1}, 0.163 \mu \mathrm{g} \cdot \mathrm{L}^{-1}$, and $0.130 \mu \mathrm{g} \cdot \mathrm{L}^{-1}$ (Table 3 ). The concentrations of urinary 2-hydroxynaphthalene (2-NAP) in preschoolers, children, adolescents, and adults were $3.37 \mu \mathrm{g} \cdot \mathrm{L}^{-1}, 2.67 \mu \mathrm{g} \cdot \mathrm{L}^{-1}, 3.05 \mu \mathrm{g} \cdot \mathrm{L}^{-1}$, and $2.63 \mu \mathrm{g} \cdot \mathrm{L}^{-1}$, respectively, notably higher for preschoolers (Table 3). The GM concentrations of urinary 1-hydroxyphenanthrene (1-OH-Phe) in preschoolers, adolescents, and adults were $0.080 \mu \mathrm{g} \cdot \mathrm{L}^{-1}, 0.127 \mu \mathrm{g} \cdot \mathrm{L}^{-1}$ and $0.117 \mu \mathrm{g} \cdot \mathrm{L}^{-1}$, respectively; whereas those of urinary 2-hydroxyfluorene (2-OH-Flu) were notably higher for preschoolers compared to children, adolescents, and adults: $0.495 \mu \mathrm{g} \cdot \mathrm{L}^{-1}$, $0.209 \mu \mathrm{g} \cdot \mathrm{L}^{-1}, 0.263 \mu \mathrm{g} \cdot \mathrm{L}^{-1}$, and $0.321 \mu \mathrm{g} \cdot \mathrm{L}^{-1}$, respectively.

The GM concentrations of urinary trans,trans-muconic acid ( $t, t-M A)$ in preschoolers, children, adolescents, and adults were $82.2 \mu \mathrm{g} \cdot \mathrm{L}^{-1}, 91.2 \mu \mathrm{g} \cdot \mathrm{L}^{-1}, 80.4 \mu \mathrm{g} \cdot \mathrm{L}^{-1}$, and $86.2 \mu \mathrm{g} \cdot \mathrm{L}^{-1}$, respectively; whereas those of urinary N-Acetyl-S-(benzyl)-L-cysteine (BMA) were $10.6 \mu \mathrm{g} \cdot \mathrm{L}^{-1}, 7.39 \mu \mathrm{g} \cdot \mathrm{L}^{-1}, 5.66 \mu \mathrm{g} \cdot \mathrm{L}^{-1}$, and $4.63 \mu \mathrm{g} \cdot \mathrm{L}^{-1}$, respectively.

\section{Discussion}

\subsection{Comparisons with Other National Biomonitoring Programs}

Comparisons were made between the results of KoNEHS Cycle 3 (2015-2017), the United States National Health and Nutrition Examination Survey (NHANES, 2015-2016), and the Canadian Health Measures Survey (CHMS, 2016-2017; Table S2).

In preschoolers, BPA $\left(2.41 \mu \mathrm{g} \cdot \mathrm{L}^{-1}\right)$ and paraben (methyl paraben: $46.3 \mu \mathrm{g} \cdot \mathrm{L}^{-1}$ and propyl paraben: $4.36 \mu \mathrm{g} \cdot \mathrm{L}^{-1}$ ) GM concentrations were 3-4 times higher than in Canada (BPA: $0.94 \mu \mathrm{g} \cdot \mathrm{L}^{-1}$, methyl paraben: $9.9 \mu \mathrm{g} \cdot \mathrm{L}^{-1}$ and propyl paraben: $1.2 \mu \mathrm{g} \cdot \mathrm{L}^{-1}$ ). In children, paraben (methyl paraben: $28.9 \mu \mathrm{g} \cdot \mathrm{L}^{-1}$ and propyl paraben: $1.83 \mu \mathrm{g} \cdot \mathrm{L}^{-1}$ ) GM concentrations were 2-3 times higher than in Canada (methyl paraben: $7.5 \mu \mathrm{g} \cdot \mathrm{L}^{-1}$ and propyl paraben: $\left.0.96 \mu \mathrm{g} \cdot \mathrm{L}^{-1}\right)$. Methyl paraben GM concentrations were similar to that of children in the US (methyl paraben: $28.9 \mu \mathrm{g} \cdot \mathrm{L}^{-1}$ ), but two times lower in adolescents (KoNEHS: $26.1 \mu \mathrm{g} \cdot \mathrm{L}^{-1}$ and US: $40.5 \mu \mathrm{g} \cdot \mathrm{L}^{-1}$ ) and adults (KoNEHS: $35.2 \mu \mathrm{g} \cdot \mathrm{L}^{-1}$ and US: $\left.52.2 \mu \mathrm{g} \cdot \mathrm{L}^{-1}\right)$.

In children and adolescents, cadmium $\left(0.232 \mu \mathrm{g} \cdot \mathrm{L}^{-1}\right.$ and $\left.0.289 \mu \mathrm{g} \cdot \mathrm{L}^{-1}\right)$ concentrations were four times higher than in the US $\left(0.057 \mu \mathrm{g} \cdot \mathrm{L}^{-1}\right.$ and $\left.0.055 \mu \mathrm{g} \cdot \mathrm{L}^{-1}\right)$, where levels were highest in the Asian ethnic group compared to others [30]. For adolescents, mercury $\left(1.37 \mu \mathrm{g} \cdot \mathrm{L}^{-1}\right) \mathrm{GM}$ concentrations were four times higher than in the US $\left(0.395 \mu \mathrm{g} \cdot \mathrm{L}^{-1}\right)$.

The DEHP metabolite and MnBP, 3-PBA GM concentrations were 2-3 times higher in all age than in the US and Canada. The concentrations are presented in detailed in Table 
S2. In particular, 3-PBA (GM 95\% CI: 1.21-1.52) in Korea was higher than those of other Asian countries, including China (GM 95\% CI: 0.08-0.97) and Japan (GM 95\% CI: 0.331.16) [31]. In adults, GM concentrations of heavy metals (Pb: $1.60 \mu \mathrm{g} \cdot \mathrm{dL}^{-1}, \mathrm{Hg}: 2.75 \mu \mathrm{g} \cdot \mathrm{L}^{-1}$ and $\left.\mathrm{Cd}: 0.359 \mu \mathrm{g} \cdot \mathrm{L}^{-1}\right)$ were $2-3$ times higher than in the US $\left(\mathrm{Pb}: 0.920 \mu \mathrm{g} \cdot \mathrm{dL}^{-1}, \mathrm{Hg}\right.$ : $0.810 \mu \mathrm{g} \cdot \mathrm{L}^{-1}$ and $\mathrm{Cd}: 0.174 \mu \mathrm{g} \cdot \mathrm{L}^{-1}$ ) and Canada (Hg: $0.72 \mu \mathrm{g} \cdot \mathrm{L}^{-1}$ and $\mathrm{Cd}: 0.22 \mu \mathrm{g} \cdot \mathrm{L}^{-1}$ ). Moreover, DEHP metabolites, and MnBP (MEHHP: $13.2 \mu \mathrm{g} \cdot \mathrm{L}^{-1}$, MEOHP: $9.88 \mu \mathrm{g} \cdot \mathrm{L}^{-1}$, MECPP: $23.2 \mu \mathrm{g} \cdot \mathrm{L}^{-1}$ and MnBP: $22.3 \mu \mathrm{g} \cdot \mathrm{L}^{-1}$ ) were $2-3$ times higher than in the US (MEHHP: $5.29 \mu \mathrm{g} \cdot \mathrm{L}^{-1}$, MEOHP: $3.29 \mu \mathrm{g} \cdot \mathrm{L}^{-1}$, MECPP: $8.12 \mu \mathrm{g} \cdot \mathrm{L}^{-1}$ and MnBP: $9.18 \mu \mathrm{g} \cdot \mathrm{L}^{-1}$ ) and Canada (MEHHP: $4.7 \mu \mathrm{g} \cdot \mathrm{L}^{-1}$, MEOHP: $3.1 \mu \mathrm{g} \cdot \mathrm{L}^{-1}$, MECPP: $5.5 \mu \mathrm{g} \cdot \mathrm{L}^{-1}$ and MnBP: $\left.11 \mu \mathrm{g} \cdot \mathrm{L}^{-1}\right)$.

\subsection{Metals}

Blood lead concentrations in adults were approximately twice those observed in adolescents, similar to the findings of other research $[4,32]$. Both drinking and smoking were associated with higher lead concentrations [33-35]. Further, it was found here that lead concentrations were higher in adults who had smoked or consumed alcohol more than three times a week $(p<0.001)$. A previous study showed that it has been shown that alcohol consumption in adults accounted for the largest proportion of changes in lead concentrations, followed by smoking [36]. Additionally, infants born to woman who smoke and drink were found to be at greater risk for lead toxicity [37]. Blood lead levels tended to decrease in all countries over time, with a notable larger decline in Korea. Korea implemented a phasing out policy on leaded gasoline from January 1, 1993, making the supply of unleaded gasoline compulsory since then. The rapid decrease in atmospheric lead concentrations, and subsequent gradual decrease in blood lead concentrations was judged to be the primary driver of the observed patterns in Korea [38].

In adolescents, blood mercury concentrations were half those of adults. Overall mercury levels were positively associated with fish, egg, meat, and vegetable intake, similar to findings that fish are a potential cause of total mercury exposure among Swedish adolescents [39]. Other studies have shown that even despite low fish consumption, they remained correlated to adolescent blood mercury concentrations [40]. Among the adults of Cycle 3, those living in the coastal regions (GM $3.34 \mu \mathrm{g} \cdot \mathrm{L}^{-1}$ ) showed higher blood mercury levels than those in urban (GM $2.76 \mu \mathrm{g} \cdot \mathrm{L}^{-1}$ ) or rural areas (GM $2.64 \mu \mathrm{g} \cdot \mathrm{L}^{-1}$; data not shown). We confirmed similar results in previous studies. It has been demonstrated that very high blood mercury levels detected in Yeongnam region of Korea were attributable to a local culture of consuming shark meat [41]. Analyzing the mercury concentrations, based on the dietary food intake records of 553 adults revealed that fish and shellfish contributed most to the mercury concentration, accounting for $77.8 \%$ of the total intake. The results showed that high exposure levels of blood mercury in Korean adults were related to the frequency of fish and shellfish intake [42]. Similar results were reported in the US NHANES data $[30,43]$.

The concentration of urinary cadmium increased with age, similar to the findings from other studies [44,45]. The primary exposure source of cadmium among the general population is food, which is related to diet [46-48], with the consumption of rice (and other cereals), a notable staple of the East Asian diet, suggested as the major cause of urinary cadmium $[49,50]$. Rice consumption of the Korean general population is higher than other Asian countries, possibly further contributing to their high cadmium exposure levels. In the present study, grain (non-adults, $p=0.004$ ) and soybean (non-adults, $p<0.001$; adults, $p<0.001$ ) intake increased with age, with a further positive correlation revealed between GM cadmium concentrations and soybean intake (non-adults, $p<0.001$; adults, $p<0.001$ ). Monitoring cadmium exposure in the Iranian population indicated that cadmium contamination occurred in food groups, such as rice, cereals, legumes, and vegetables. Specifically, $75 \%$ of the consumed rice samples showed cadmium concentrations higher than the maximum cadmium limit $\left(0.06 \mathrm{mg} \cdot \mathrm{kg}^{-1}\right)$ allowed by the Institute of Standards and Industrial Research of Iran (ISIRI) [51]. In addition, canned fish (mean: $0.032 \mu \mathrm{g} \cdot \mathrm{g}^{-1}$ ) and tuna (mean: 
$0.022 \mu \mathrm{g} \cdot \mathrm{g}^{-1}$ ) samples showed high cadmium concentrations (ISIRI: $0.05 \mathrm{mg} \cdot \mathrm{kg}^{-1}$ ) [52,53]. Therefore, a more detailed analysis of food types, consumption frequency, and consumption patterns is required.

\subsection{Phthalates Metabolites, BPA, and TCS}

The concentrations of phthalate, BPA, and TCS in this analysis were higher in preschoolers and children. Children's ratio of body area to body weight is higher than that of adults, so any correlated exposure to harmful substances through the skin is higher $[54,55]$.

Several studies have similarly shown that the younger the age, the higher the concentration of phthalates in one's body [56]. Estimating phthalate concentrations in 129 Danish children and adolescents (6-21 years) showed that phthalates were detectable in almost all samples, that youngest children were generally more exposed to phthalates than older children and adolescents [57]. The results of a Portuguese study showed that a healthy diet consisting of fresh, unprocessed or less packaged foods can significantly reduce phthalate intake in children [58]. It was also found that phthalate intakes may be lower in children on a healthy diet $(p<0.05)$ than on a common diet. Several findings have confirmed that childhood phthalate exposure is associated with obesity [59-61], which indicates the need for continued management of phthalate exposure in growing children. Although phthalates can cause endocrine disorders, they are widely used in cosmetics, toys, detergents, and household flooring; thus, the mouthing behavior of infants and toddlers could potentially increase their exposure from toys and other products made with plasticized polymers [55]. The younger the children, the greater the frequency of consuming boiled water from plastic containers $(p<0.001)$, and the correlated MEHHP and MEOHP GM concentrations were significantly high ( $p=0.005, p=0.019$, respectively).

Higher BPA levels in younger ages have also been observed in several other studies [62-64]. BPA is commonly used in various products for everyday use, including water-pipes, electronic equipment, paper, or toys [65]. A Greek child cohort study showed that BPA was associated with exposure to plastics and personal care products. In addition, the risk of neurotoxic activity makes BPA more likely to affect children's health more readily [66]. For children, the amount of percutaneous chemical absorption is three times that of adults, with particular exposure risks to harmful substances adsorbed on flooring, or other indoor products $[67,68]$. Food is the most important source of BPA exposure in the general population [7]. Particularly, canned foods have been shown to maintain significantly higher rates of BPA exposure, as it is released from lacquer coatings on the tins $[69,70]$. Although exposure sources, such as canned beverages and canned foods, were analyzed here, no significant correlations with BPA concentrations were observed, whereas liquids and other consumer products in polycarbonate containers have previously been shown to increase urinary BPA [71].

When investigating the association between TCS and the use of personal care products, the former was detected in $>70 \%$ of children, with notable higher concentrations in the group using hand soap, increasing with the frequency of hand washing. Additionally, the use of toothpaste by children was also positively related to TCS, further explaining its high correlation with personal care products [72]. In the present study, higher frequency use of antibacterial products $(p=0.021)$ lead to higher concentrations of TCS in non-adults, whereas adult concentrations were significantly correlated to frequency of body wash use $(p=0.041)$.

\subsection{Parabens}

In the case of methyl and propyl paraben (commonly used together), concentrations in preschoolers were relatively higher. Parabens are often used as preservatives in medicines, such as pills and liquid antipyretics [73], both of which are commonly consumed by preschoolers [74-77]. Generally higher urinary methyl and propyl paraben concentrations among adult females can be explained by the more frequent use of personal care products among females, as both are commonly used as preservatives in such items [78]. A previous 
study of paraben concentrations in the urine of the Belgian population also showed that paraben exposure patterns differ significantly between children and adults, and between men and women [79]. The levels of methyl $\left(33.5 \mu \mathrm{g} \cdot \mathrm{L}^{-1}, p<0.001\right)$ and propyl $\left(3.3 \mu \mathrm{g} \cdot \mathrm{L}^{-1}\right.$, $p<0.001)$ parabens were higher in women, highlighting their association with cosmetic and personal care product use. For both methyl and propyl paraben, males were higher in infancy, whereas females were far higher in adolescence and adulthood. Methyl paraben is one of the most frequently used preservatives in cosmetic products such as lipsticks, perfumes, and personal care products [80], thus potentially explaining the higher levels found in girls [81]. Ethyl paraben showed the highest concentrations in adults, where urinary levels were positively associated with the consumption of fast and canned foods. Use of liquid soaps, including shower gel and shampoo, was also associated with ethyl paraben levels [77]. An analysis of ethyl paraben intake by food type according to the result of the Korea National Health and Nutrition Examination Survey, found it was primarily consumed through sauces and mixed soy sauce [82]. Therefore, further detailed analyses are needed on food types, ingredients, and current consumption patterns.

\subsection{3-PBA and Cotinine}

The GM concentrations of urinary 3-PBA in children was slightly higher than that of other age groups. Further, children $<9$ years had greater 3-PBA concentrations when living in rural residential apartments compared to similar urban locations, indicating the effects of landscaping pesticides on nearby playgrounds and public areas [83]. Various studies have found that sprays and fumigant-type insecticides were also important contributors to 3-PBA exposure of the Korean population [7,84,85]. In adults, 3-PBA concentration were higher when more time was spent at home $(p=0.0006)$ than outdoors, and coffee intake was also found to have an effect $(p=0.007)$ [86]. Further research is needed regarding exposure from consuming beverages and foods, as well as the amount of time spent indoors and outdoors.

Adolescent males showed significantly higher cotinine concentrations than females. As age increased, the number of male adolescents who started smoking increased while the number of female adolescents decreased [87]. According to the KoNEHS Cycle 3 survey results, the smoking rate was 3.1\% for adolescents (63\% male, 31\% female, $6 \%$ do not know), and $15.9 \%$ for adults (90\% male, $10 \%$ female). As the frequency of secondhand smoke increased, so too did cotinine concentrations [88], indicating the potential indirect effects of smoking on children and adolescents. It was confirmed that cotinine concentrations in non-adults were higher if there was a smoker in the family $(p<0.001)$, or when more time was spent exposed to secondhand smoke $(p<0.001)$. Adults also showed higher cotinine concentrations with family smokers present $(p<0.001)$, and secondhand smoke exposure $(p=0.001)$.

\subsection{PAH and VOC Metabolites}

The GM concentrations of urinary 2-NAP and 2-OH-Flu in preschoolers were significantly higher than the other age ranges. When food was cooked using gas, 2-NAP concentrations were significantly higher in non-adults $(p=0.005)$, whereas increased frequencies of charcoal grilling was correlated with higher 1-OH-Phe concentrations in non-adults $(p=0.032)$. PAHs metabolites were detected in over $78 \%$ of urine samples from 522 children, aged 5-12 years of Valencia, Spain, and 2-NAP was detection rate in $100 \%$. In addition to the consumption of legumes and packaged foods, the education level, demographic characteristics, socioeconomic characteristics were previously identified as the most relevant factors influencing PAHs exposure levels in children [89]. Children were more susceptible to PAHs exposure than adults [90], and higher concentrations of PAH metabolites were found when household cooking was conducted with heating fuels and gases [91]. The concentrations of 1-OH-Pyr, 2-NAP, 1-OH-Phe, and 2-OH-Flu in adults were all significantly higher when petroleum was used as the household heating fuel $(p=0.001$, $p<0.001, p<0.001$, and $p=0.001$, respectively). Elsewhere, studies have indicated that diet, 
smoking, and air pollution were major determinants of internal PAHs exposure [91-93]. In addition to one's smoking status, the consumption of certain foods (such as vegetables, oils and fats, smoked fish and coffee) has been shown to be a major factor influencing PAHs exposure [94]. Further research is needed on the exposure to different types of heating fuels, food intake and cooking methods.

The $t, t-M A$ concentrations were higher in men than women, across all ages (Table S3), and exposure levels were significantly higher in smokers than non-smokers $[95,96]$. The higher smoking rate among men is thought to drive these patterns. Additionally, food consumption containing sorbic acid may be another potential source $t, t-M A$. Sorbic acid is used as a preservative, and $\sim 0.05-0.5 \%$ is metabolized to $t, t-M A$ after ingestion [97].

The GM concentrations of urinary BMA in preschoolers were $10.6 \mu \mathrm{g} \cdot \mathrm{L}^{-1}$, significantly higher than either children or adolescents $\left(7.39 \mu \mathrm{g} \cdot \mathrm{L}^{-1}\right.$, and $5.66 \mu \mathrm{g} \cdot \mathrm{L}^{-1}$, respectively). According to the results of the National Health and Nutrition Survey in the US, the BMA concentrations in children were higher than in adults. This can be explained either by higher childhood levels of exposure to chemicals, such as ethylbenzene-styrene and toluene, or slower excretion rates than that of adults [98]. A previous study of urban childcare facilities found the detected VOC metabolites was correlated to the use of chlorine bleach and scented candles; thus, higher concentrations could be related to the exposure of children spending greater amounts of time in childcare facilities compared to home [99].

\section{Conclusions}

The KoNEHS is the largest biomonitoring survey capable of identifying environmental chemical exposure levels across a nationally representative population. The most current exposure profiles for major environmental chemicals among the Korean population, KoNEHS Cycle 3 (2015-2017), is summarized here.

In Korean children and adolescents, concentrations of mercury and cadmium were higher than in other countries. Although these levels are not of great concern when compared with Human Biomonitoring Commission recommendations, continuous observations are required to ensure they are not deleteriously affecting children's growth, development, or health.

BPA and paraben levels were also high; further studies are needed due to the increased use of bisphenol substitutes (bisphenol F, S) and parabens, and there were different trends according to gender and age. In addition, the levels of phthalate biomarkers measured in the KoNEHS were higher in children and adolescents than in adults. Accordingly, the results indicated the need for exposure reduction measures throughout basic lifestyle and daily life, while continuously monitoring children's exposure in particular. Among Korean adults, lead, mercury, cadmium, metabolites of DEHP and DnBP, and 3-PBA levels were higher than those reported in the US or Canada; however, their concentrations have been decreasing with time. Urinary BPA and t,t-MA concentrations showed an increasing trend, both warranting further studies on their exposure pathways.

For children and adolescents, the Cycle 3 survey represented the first national biomonitoring results. Although it was not possible to explain the exact mechanism of substances with a large concentration difference compared to foreign standards, it is believed that the effect will be due to differences in dietary habits and the resulting basic body shape and living environment. Additional research is needed on the effects of exposure to environmental chemical substances. Moving forward, if data are secured through continuous surveys, it will be possible to identify various exposure factors by comparing data over time and analyzing connections within the survey results. Furthermore, The Ministry of Environment of Korea has established a "concentration standard in the human body" and is conducting a detailed investigation by reviewing whether these are exceeded through the results of the KoNEHS. Findings from these efforts will be used to develop environmental health policies, and appropriate mitigation measures for protecting the health of the people. 
Supplementary Materials: The following are available online at https:/ /www.mdpi.com/article/10 .3390 /ijerph19020626/s1, Table S1: Comparison of target chemicals and analytical methods in Cycle 1 (2009-2011), Cycle 2 (2012-2014), and Cycle 3 (2015-2017) of the KoNEHS; Table S2: Concentrations of target chemicals from the national biomonitoring programs of Korea, USA, and Canada. Units for all chemicals are in $\left(\mu \mathrm{g} \cdot \mathrm{L}^{-1}\right)$, except for lead $\left(\mu \mathrm{g} \cdot \mathrm{dL}^{-1}\right)$. For pre- and elementary schoolers, blood lead and mercury were not measured.; Table S3: Concentration distributions of the 26 environmental chemicals for the Korean population KoNEHS Cycle 3 (2015-2017), compared to Cycles 1 and 2. LOD, limit of detection; AM, arithmetic mean; GM, geometric mean. Units are in $\mu \mathrm{g} \cdot \mathrm{L}^{-1}$ unless otherwise specified.

Author Contributions: Conceptualization, S.K.J.; methodology, S.K.J., W.C. and S.Y.K.; software, S.K.J.; validation, S.K.J., H.L.J. and S.H.; formal analysis, S.K.J.; writing-original draft preparation, S.K.J.; writing—review and editing, S.K.J., S.H., H.L.J., Y.J., C.L., K.C., S.K., K.-J.L. and J.Y.; All authors have read and agreed to the published version of the manuscript.

Funding: This survey was supported by a grant from the National Institute of Environmental Research (NIER), funded by the Ministry of Environment of Korea (NIER-2017-01-01-001).

Institutional Review Board Statement: This survey was approved by the Institutional Review Board of the National Institute of Environmental Research (NIER), Korea (NIER-2015-BR-006-01).

Informed Consent Statement: Not applicable.

Data Availability Statement: In this study we used data from the Korean National Environmental Health Survey (KoNEHS) Cycle 3, which was conducted by Ministry of Environment, National Institute of Environmental Research. The data presented are available on request from the corresponding author.

Acknowledgments: The authors thank all members who participated in the KoNEHS Cycle 3 (20152017) for their co-operation and support.

Conflicts of Interest: The authors declare no conflict of interest.

\section{References}

1. Paustenbach, D.; Galbraith, D. Biomonitoring: Is Body Burden Relevant to Public Health? Regul. Toxicol. Pharmacol. 2006, 44, 249-261. [CrossRef] [PubMed]

2. Angerer, J.; Ewers, U.; Wilhelm, M. Human Biomonitoring: State of the Art. Int. J. Hyg. Environ. Health 2007, 210, 201-228. [CrossRef]

3. NRC (National Research Council). National Research Council's Human Biomonitoring for Environmental Chemicals; National Academy of Sciences: Washington, DC, USA, 2006.

4. Schulz, C.; Conrad, A.; Becker, K.; Kolossa-Gehring, M.; Seiwert, M.; Seifert, B. Twenty Years of the German Environmental Survey (GerES): Human Biomonitoring- Temporal and Spatial (West Germany/East Germany) Differences in Population Exposure. Int. J. Hyg. Environ. Health 2007, 210, 271-297. [CrossRef] [PubMed]

5. World Health Organization. Human Biomonitoring: Facts and Figures. Copenhagen: World Health Organization Regional Office for Europe; WHO: Copenhagen, Denmark, 2015.

6. CDC (Centers for Disease Control and Prevention). Fourth National Report on Human Exposure to Environmental Chemicals; Centers for Disease Control and Prevention, Division of Laboratory Sciences: Atlanta, GA, USA, 2019.

7. Health Canada. Fifth Report on Human Biomonitoring of Environmental Chemicals in Canada; Health Canada: Ottawa, ON, Canada, 2019.

8. Calafat, A.M.; Kuklenyik, Z.; Caudill, S.P.; Reidy, J.A.; Needham, L.L. Perfluorochemicals in Pooled Serum Samples from United States Residents in 2001 and 2002. Environ. Sci. Technol. 2006, 40, 2128-2134. [CrossRef] [PubMed]

9. Haines, D.A.; Saravanabhavan, G.; Werry, K.; Khoury, C. An Overview of Human Biomonitoring of Environmental Chemicals in the Canadian Health Measures Survey: 2007-2019. Int. J. Hyg. Environ. Health 2017, 220, 13-28. [CrossRef] [PubMed]

10. Health Canada. Custom Analysis of National Biomonitoring Data from the Canadian Health Measures Survey. Available upon Request. Available online: https://www.statcan.gc.ca/en/survey/household/5071 (accessed on 20 November 2021).

11. Choi, W.; Kim, S.; Baek, Y.W.; Choi, K.; Lee, K.; Kim, S.; Yu, S.D.; Choi, K. Exposure to Environmental Chemicals among Korean Adults-Updates from the Second Korean National Environmental Health Survey (2012-2014). Int. J. Hyg. Environ. Health 2017, 220, 29-35. [CrossRef]

12. Park, C.; Hwang, M.; Kim, H.; Ryu, S.; Lee, K.; Choi, K.; Paek, D. Early Snapshot on Exposure to Environmental Chemicals among Korean Adults-Results of the First Korean National Environmental Health Survey (2009-2011). Int. J. Hyg. Environ. Health 2016, 219, 398-404. [CrossRef] 
13. Kolossa-Gehring, M.; Becker, K.; Conrad, A.; Lüdecke, A.; Riedel, S.; Seiwert, M.; Schulz, C.; Szewzyk, R. German Environmental Survey for Children (GerES IV)-First Results. Int. J. Hyg. Environ. Health 2007, 210, 535-540. [CrossRef] [PubMed]

14. Sexton, K.; Adgate, J.L.; Church, T.R.; Ashley, D.L.; Needham, L.L.; Ramachandran, G.; Fredrickson, A.L.; Ryan, A.D. Children's Exposure to Volatile Organic Compounds as Determined by Longitudinal Measurements in Blood. Environ. Health Perspect. 2005, 113, 342-349. [CrossRef]

15. Wang, R.Y.; Needham, L.L.; Barr, D.B. Effects of Environmental Agents on the Attainment of Puberty: Considerations When Assessing Exposure to Environmental Chemicals in the National Children's Study. Environ. Health Perspect. 2005, 113, $1100-1107$. [CrossRef] [PubMed]

16. Landrigan, P.J.; Goldman, L.R. Children's Vulnerability to Toxic Chemicals: A Challenge and Opportunity to Strengthen Health and Environmental Policy. Health Aff. 2011, 30, 842-850. [CrossRef] [PubMed]

17. NIER (National Institute of Environmental Research). Environmental Exposure and Health Survey in Children and Adolescents (I); Korea Ministry of Environment, National Institute of Environmental Research, Environmental Health Research Division: Incheon, Korea, 2012. Available online: https:/ / ecolibrary.me.go.kr/nier/\#/search/detail/5515066 (accessed on 20 November 2021).

18. NIER (National Institute of Environmental Research). Environmental Exposure and Health Survey in Children and Adolescents (IV); Korea Ministry of Environment, National Institute of Environmental Research, Environmental Health Research Division: Incheon, Korea, 2014. Available online: https:/ / ecolibrary.me.go.kr/nier/\#/search/detail/5592827 (accessed on 20 November 2021).

19. Burm, E.; Song, I.; Ha, M.; Kim, Y.M.; Lee, K.J.; Kim, H.C.; Lim, S.; Kim, S.Y.; Lee, C.G.; Kim, S.Y.; et al. Representative Levels of Blood Lead, Mercury, and Urinary Cadmium in Youth: Korean Environmental Health Survey in Children and Adolescents (KorEHS-C), 2012-2014. Int. J. Hyg. Environ. Health 2016, 219, 412-418. [CrossRef] [PubMed]

20. Leppert, B.; Strunz, S.; Seiwert, B.; Schlittenbauer, L.; Schlichting, R.; Pfeiffer, C.; Röder, S.; Bauer, M.; Borte, M.; Stangl, G.I.; et al. Maternal Paraben Exposure Triggers Childhood Overweight Development. Nat. Commun. 2020, 11, 561. [CrossRef] [PubMed]

21. Darbre, P.D.; Harvey, P.W. Paraben Esters: Review of Recent Studies of Endocrine Toxicity, Absorption, Esterase and Human Exposure, and Discussion of Potential Human Health Risks. J. Appl. Toxicol. 2008, 28, 561-578. [CrossRef] [PubMed]

22. Ijaz, S.; Ullah, A.; Shaheen, G.; Jahan, S. Exposure of BPA and Its Alternatives Like BPB, BPF, and BPS Impair Subsequent Reproductive Potentials in Adult Female Sprague Dawley Rats. Toxicol. Mech. Methods 2020, 30, 60-72. [CrossRef] [PubMed]

23. Ullah, A.; Pirzada, M.; Jahan, S.; Ullah, H.; Razak, S.; Rauf, N.; Khan, M.J.; Mahboob, S.Z. Prenatal BPA and Its Analogs BPB, BPF, and BPS Exposure and Reproductive Axis Function in the Male Offspring of Sprague Dawley Rats. Hum. Exp. Toxicol. 2019, 38, 1344-1365. [CrossRef] [PubMed]

24. Liu, B.; Lehmler, H.J.; Sun, Y.; Xu, G.; Sun, Q.; Snetselaar, L.G.; Wallace, R.B.; Bao, W. Association of Bisphenol A and Its Substitutes, Bisphenol F and Bisphenol S, with Obesity in United States Children and Adolescents. Diabetes Metab. J. 2019, 43, 59-75. [CrossRef]

25. Ha, M.; Kwon, H.J.; Leem, J.H.; Kim, H.C.; Lee, K.J.; Park, I.; Lim, Y.W.; Lee, J.H.; Kim, Y.; Seo, J.H.; et al. Korean Environmental Health Survey in Children and Adolescents (KorEHS-C): Survey Design and Pilot Study Results on Selected Exposure Biomarkers. Int. J. Hyg. Environ. Health 2014, 217, 260-270. [CrossRef]

26. NIER (National Institute of Environmental Research). Guideline for Biological Specimens Management on Cycle 3 of the Korean National Environmental Health Survey; Korea Ministry of Environment, National Institute of Environmental Research, Environmental Health Research Division: Seo-gu, Korea, 2015.

27. NIER (National Institute of Environmental Research). Manual for Laboratory Procedures on Cycle 3 of the Korean National Environmental Health Survey (Heavy Metals); Korea Ministry of Environment, National Institute of Environmental Research, Environmental Health Research Division: Seo-gu, Korea, 2018. Available online: https:/ / ecolibrary.me.go.kr/nier/\#/search/detail/5716907 (accessed on 20 November 2021).

28. NIER (National Institute of Environmental Research). Manual for Laboratory Procedures on Cycle 3 of the Korean National Environmental Health Survey (Organic Chemicals); Korea Ministry of Environment, National Institute of Environmental Research, Environmental Health Research Division: Seo-gu, Korea, 2018. Available online: https:/ / ecolibrary.me.go.kr/nier/\#/search/detail/5716906 (accessed on 20 November 2021).

29. Hornung, R.W.; Reed, L.D. Estimation of Average Concentration in the Presence of Nondetectable Values. Appl. Occup. Environ. Hyg. 1990, 5, 46-51. [CrossRef]

30. Awata, H.; Linder, S.; Mitchell, L.E.; Delclos, G.L. Association of Dietary Intake and Biomarker Levels of Arsenic, Cadmium, Lead, and Mercury among Asian Populations in the United States: NHANES 2011-2012. Environ. Health Perspect. 2017, 125, 314-323. [CrossRef]

31. Tang, W.; Wang, D.; Wang, J.; Wu, Z.; Li, L.; Huang, M.; Xu, S.; Yan, D. Pyrethroid Pesticide Residues in the Global Environment: An Overview. Chemosphere 2018, 191, 990-1007. [CrossRef] [PubMed]

32. Cerna, M.; Krskova, A.; Cejchanova, M.; Spevackova, V. Human. Human Biomonitoring in the Czech Republic: An Overview. Int. J. Hyg. Environ. Health 2012, 215, 109-119. [CrossRef]

33. Bjermo, H.; Sand, S.; Nälsén, C.; Lundh, T.; Enghardt Barbieri, H.; Pearson, M.; Lindroos, A.K.; Jönsson, B.A.; Barregård, L.; Darnerud, P.O. Lead, Mercury, and cadmium in Blood and Their Relation to Diet among Swedish Adults. Food Chem. Toxicol. 2013, 57, 161-169. [CrossRef]

34. Kim, N.S.; Lee, B.K. National Estimates of Blood Lead, Cadmium, and Mercury Levels in the Korean General Adult Population. Int. Arch. Occup. Environ. Health 2011, 84, 53-63. [CrossRef] 
35. Jeong, S.W.; Lee, C.K.; Suh, C.H.; Kim, K.H.; Son, B.C.; Kim, J.H.; Lee, J.T.; Lee, S.W.; Park, Y.B.; Lee, J.W.; et al. Blood Lead Concentration and Related Factors in Korea from the 2008 National Survey for Environmental Pollutants in the Human Body. Int. J. Hyg. Environ. Health 2014, 217, 871-877. [CrossRef] [PubMed]

36. Weyermann, M.; Brenner, H. Alcohol Consumption and Smoking Habits as Determinants of Blood Lead Levels in a National Population Sample from Germany. Arch. Environ. Health 1997, 52, 233-239. [CrossRef]

37. Lee, M.G.; Chun, O.K.; Song, W.O. Determinants of the Blood Lead Level of US Women of Reproductive Age. J. Am. Coll. Nutr. 2005, 24, 1-9. [CrossRef]

38. Oh, S.E.; Kim, G.B.; Hwang, S.H.; Ha, M.; Lee, K.M. Longitudinal Trends of Blood Lead Levels before and after Leaded Gasoline Regulation in Korea. Environ. Health Toxicol. 2017, 32, e2017019. [CrossRef] [PubMed]

39. Almerud, P.; Zamaratskaia, G.; Lindroos, A.K.; Bjermo, H.; Andersson, E.M.; Lundh, T.; Ankarberg, E.H.; Lignell, S. Cadmium, Total Mercury, and Lead in Blood and Associations with Diet, Sociodemographic Factors, and Smoking in Swedish Adolescents. Environ. Res. 2021, 197, 110991. [CrossRef]

40. Bárány, E.; Bergdahl, I.A.; Bratteby, L.E.; Lundh, T.; Samuelson, G.; Skerfving, S.; Oskarsson, A. Mercury and Selenium in Whole Blood and Serum in Relation to Fish Consumption and Amalgam Fillings in Adolescents. J. Trace Elem. Med. Biol. 2003, 17, 165-170. [CrossRef]

41. Kim, D.S.; Kwon, Y.M.; Chung, H.U.; Choi, K. Mercury Exposure Factors among Residents of the High Mercury Exposure Area Seoksan-ri, Korea. J. Environ. Health Sci. 2015, 41, 349-357. [CrossRef]

42. Kim, S.A.; Kwon, Y.M.; Kim, S.; Joung, H. Assessment of Dietary Mercury Intake and Blood Mercury Levels in the Korean Population: Results from the Korean National Environmental Health Survey 2012-2014. Int. J. Environ. Res. Public Health 2016, 13, 877. [CrossRef]

43. Xue, J.; Zartarian, V.G.; Liu, S.V.; Geller, A.M. Methyl Mercury Exposure from Fish Consumption in Vulnerable Racial/Ethnic Populations: Probabilistic SHEDS-Dietary Model Analyses Using 1999-2006 NHANES and 1990-2002 TDS Data. Sci. Total Environ. 2012, 414, 373-379. [CrossRef]

44. Garner, R.; Levallois, P. Cadmium Levels and Sources of Exposure among Canadian Adults. Health Rep. 2016, 27, 10-18. [PubMed]

45. Ruiz, P.; Mumtaz, M.; Osterloh, J.; Fisher, J.; Fowler, B.A. Interpreting NHANES Biomonitoring Data, Cadmium. Toxicol. Lett. 2010, 198, 44-48. [CrossRef]

46. Zhang, Z.W.; Moon, C.S.; Watanabe, T.; Shimbo, S.; He, F.S.; Wu, Y.Q.; Zhou, S.F.; Su, D.M.; Qu, J.B.; Ikeda, M. Background Exposure of Urban Populations to Lead and Cadmium: Comparison between China and Japan. Int. Arch. Occup. Environ. Health $1997,69,273-281$.

47. Järup, L.; Åkesson, A. Current Status of Cadmium as an Environmental Health Problem. Toxicol. Appl. Pharmacol. 2009, 238, 201-208. [CrossRef]

48. NIER (National Institute of Environmental Research). Aggregate Risk Assessment Report: Cadmium; Korea Ministry of Environment, National Institute of Environmental Research, Risk assessment Division: Incheon, Korea, 2017.

49. Tsukahara, T.; Ezaki, T.; Moriguchi, J.; Furuki, K.; Shimbo, S.; Matsuda-Inoguchi, N.; Ikeda, M. Rice as the Most Influential Source of Cadmium Intake among General Japanese Population. Sci. Total Environ. 2003, 305, 41-51. [CrossRef]

50. Lin, L.; Zhou, W.; Dai, H.; Cao, F.; Zhang, G.; Wu, F. Selenium Reduces Cadmium Uptake and Mitigates Cadmium Toxicity in Rice. J. Hazard. Mater. 2012, 235-236, 343-351. [CrossRef] [PubMed]

51. Ghoochani, M.; Rastkari, N.; Yunesian, M.; Nodehi, R.N.; Mesdaghinia, A.; Houshiarrad, A.; Shamsipour, M.; Dehghani, M.H. What do We Know about Exposure of Iranians to Cadmium? Findings from a Systematic Review. Environ. Sci Pollut Res. Int. 2018, 2, 1-11. [CrossRef]

52. Malakootian, M.; Tahergorabi, M.; Daneshpajooh, M.; Amirtaheri, K. Determination of Pb, Cd, Ni, Zn Concentration in Canned Fish in South of Iran. Hormozgan Med. J. 2013, 16, 445-451.

53. Khansari, F.E.; Ghazi-Khansari, M.; Abdollahi, M. Heavy Metals Content of Canned Tuna Fish. Food chem 2005, 93, 293-296. [CrossRef]

54. Braun, J.M.; Sathyanarayana, S.; Hauser, R. Phthalate Exposure and Children's Health. Curr. Opin. Pediatr. 2013, 25, 247-254. [CrossRef]

55. Pesticide Action Network UK. England and Wales. 2013. Available online: https://www.pan-uk.org/effects-pesticides-womenchildren/ (accessed on 20 November 2021).

56. Wang, Y.; Zhu, H.; Kannan, K. A Review of Biomonitoring of Phthalate Exposures. Toxics 2019, 7, 21. [CrossRef]

57. Frederiksen, H.; Aksglaede, L.; Sorensen, K.; Skakkebaek, N.E.; Juul, A.; Andersson, A.M. Urinary Excretion of Phthalate Metabolites in 129 Healthy Danish Children and Adolescents: Estimation of Daily Phthalate Intake. Environ. Res. 2011, 111, 656-663. [CrossRef] [PubMed]

58. Correia-Sá, L.; Kasper-Sonnenberg, M.; Pälmke, C.; Schütze, A.; Norberto, S.; Calhau, C.; Domingues, V.F.; Koch, H.M. Obesity or Diet? Levels and Determinants of Phthalate Body Burden-A Case Study on Portuguese Children. Int. J. Hyg. Environ. Health 2018, 22, 519-530. [CrossRef] [PubMed]

59. Buckley, J.P.; Engel, S.M.; Braun, J.M.; Whyatt, R.M.; Daniels, J.L.; Mendez, M.A.; Richardson, D.B.; Xu, Y.; Calafat, A.M.; Wolff, M.S.; et al. Prenatal Phthalate Exposures and Body Mass Index among 4 to 7 year Old Children: A Pooled Analysis. Epidemiology 2016, 27, 449. [CrossRef] [PubMed] 
60. Buckley, J.P.; Engel, S.M.; Mendez, M.A.; Richardson, D.B.; Daniels, J.L.; Calafat, A.M.; Wolff, M.S.; Herring, A.H. Prenatal Phthalate Exposures and Childhood Fat Mass in a New York City Cohort. Environ. Health Perspect 2016, 124, 507-513. [CrossRef] [PubMed]

61. Braun, J.M. Early-life Exposure to EDCs: Role in Childhood Obesity and Neurodevelopment. Nat. Rev. Endocrinol. 2017, 13, 161-173. [CrossRef] [PubMed]

62. Lehmler, H.J.; Liu, B.; Gadogbe, M.; Bao, W. Exposure to Bisphenol A, Bisphenol F, and Bisphenol S in U.S. Adults and Children: The National Health and Nutrition Examination Survey 2013-2014. A.C.S. Omega 2018, 3, 6523-6532. [CrossRef]

63. Calafat, A.M.; Ye, X.; Wong, L.Y.; Reidy, J.A.; Needham, L.L. Exposure of the U.S. Population to Bisphenol A and 4-TertiaryOctylphenol: 2003-2004. Environ. Health Perspect. 2008, 116, 39-44. [CrossRef] [PubMed]

64. Frederiksen, H.; Aksglaede, L.; Sorensen, K.; Nielsen, O.; Main, K.M.; Skakkebaek, N.E.; Juul, A.; Andersson, A.M. Bisphenol A and Other Phenols in Urine from Danish Children and Adolescents Analyzed by Isotope Diluted TurboFlow-LC-MS/MS. Int. J. Hyg. Environ. Health 2013, 216, 710-720. [CrossRef]

65. Huang, T.; Danaher, L.A.; Brüschweiler, B.J.; Kass, G.E.; Merten, C. Naturally occurring bisphenol F in plants used in traditional medicine. Arch. Toxicol. 2019, 93, 1485-1490. [CrossRef] [PubMed]

66. Myridakis, A.; Chalkiadaki, G.; Fotou, M.; Kogevinas, M.; Chatzi, L.; Stephanou, E.G. Exposure of Preschool-age Greek Children (RHEA Cohort) to Bisphenol a, Parabens, Phthalates, and Organophosphates. Environ. Sci. Technol. 2016, 50, 932-941. [CrossRef] [PubMed]

67. Kim, S.J.; Bitna, Y.; Park, M.J.; Shin, H.J.; Yang, M.H. Exposure to Bisphenol A and Girls' Endocrine Disorders. Cancer Prev. Res. 2010, 15, 106-110.

68. Lv, Y.; Rui, C.; Dai, Y.; Pang, Q.; Li, Y.; Fan, R.; Lu, S. Exposure of Children to BPA through Dust and the Association of Urinary BPA and Triclosan with Oxidative Stress in Guangzhou, China. Environ. Sci. Process Impacts 2016, 18, 1492-1499. [CrossRef] [PubMed]

69. Lorber, M.; Schecter, A.; Paepke, O.; Shropshire, W.; Christensen, K.; Birnbaum, L. Exposure Assessment of Adult Intake of Bisphenol A (BPA) with Emphasis on Canned Food Dietary Exposures. Environ. Int. 2015, 77, 55-62. [CrossRef] [PubMed]

70. Michałowicz, J. Bisphenol A-Sources, Toxicity and Biotransformation. Environ. Toxicol. Pharmacol. 2014, 37, 738-758. [CrossRef] [PubMed]

71. Trasande, L.; Attina, T.M.; Blustein, J. Association between Urinary Bisphenol A Concentration and Obesity Prevalence in Children and Adolescents. JAMA 2012, 308, 1113-1121. [CrossRef] [PubMed]

72. Stacy, S.L.; Eliot, M.; Etzel, T.; Papandonatos, G.; Calafat, A.M.; Chen, A.; Hauser, R.; Lanphear, B.P.; Sathyanarayana, S.; Ye, X.; et al. Patterns, Variability, and Predictors of Urinary Triclosan Concentrations during Pregnancy and Childhood. Environ. Sci. Technol. 2017, 51, 6404-6413. [CrossRef] [PubMed]

73. Brand, W.; Boon, P.E.; Hessel, E.V.S.; Meesters, J.A.J.; Weda, M.; Schuur, A.G. Exposure to and toxicity of methyl-, ethyl-and propylparaben: A literature review with a focus on endocrine-disrupting properties. RIVM Rep. 2018, $2017,28$.

74. Bouwman-Boer, Y.; Fenton-May, V.; Le Brun, P. Practical Pharmaceutics; KNMP: Deen Hag, The Netherlands; Springer International Publishing: Cham, Switzerland, 2015.

75. Mayoral, C.E.; Marino, R.V.; Rosenfeld, W.; Greensher, J. Alternating Antipyretics: Is This an Alternative? Pediatrics 2000, 105, 1009-1012. [CrossRef]

76. Moreta, C.; Tena, M.T.; Kannan, K. Analytical Method for the Determination and a Survey of Parabens and Their Derivatives in Pharmaceuticals. Environ. Res. 2015, 142, 452-460. [CrossRef]

77. Karthikraj, R.; Kannan, K. Human biomonitoring of select ingredients in cosmetics. In Analysis of Cosmetic Products; Elsevier: Amsterdam, The Netherlands, 2018; pp. 387-434.

78. Hong, S.; Jeon, H.L.; Lee, J.; Kim, S.; Lee, C.; Lee, S.; Cho, Y.H.; Choi, K.; Yoo, J. Urinary parabens and their potential sources of exposure among Korean children and adolescents: Korean National Environmental Health Survey 2015-2017. Int. J. Hyg. Environ. Health 2021, 236, 113781. [CrossRef]

79. Dewalque, L.; Pirard, C.; Charlier, C. Measurement of Urinary Biomarkers of Parabens, Benzophenone-3, and Phthalates in a Belgian Population. BioMed Res. Int. 2014, 2014, 649314. [CrossRef] [PubMed]

80. Soni, M.G.; Taylor, S.L.; Greenberg, N.A.; Burdock, G.A. Evaluation of the Health Aspects of Methyl Paraben: A Review of the Published Literature. Food Chem. Toxicol. 2002, 40, 1335-1373. [CrossRef]

81. Tkalec, Ž.; Kosjek, T.; Snoj Tratnik, J.; Stajnko, A.; Runkel, A.A.; Sykiotou, M.; Mazej, D.; Horvat, M. Exposure of Slovenian Children and Adolescents to Bisphenols, Parabens and Triclosan: Urinary Levels, Exposure Patterns, Determinants of Exposure and Susceptibility. Environ. Int. 2021, 146, 106172. [CrossRef] [PubMed]

82. Jo, A.; Kim, S.; Ji, K.; Kho, Y.; Choi, K. Influence of Vegetarian Dietary Intervention on Urinary Paraben Concentrations: A Pilot Study with "Temple Stay" Participants. Toxics 2020, 8, 3. [CrossRef] [PubMed]

83. Jo, H.M.; Ha, M.; Lee, W.J. Urinary Concentration of 3-Phenoxybenzoic Acid in Elementary Students in South Korea. Environ. Health Toxicol. 2015, 30, e2015009. [CrossRef]

84. EPA (US Environmental Protection Agency). Reregistration Eligibility Decision (RED) for Permethrin: Case no. 2510; Office of Pesticide Programs, EPA (US Environmental Protection Agency): Washington, DC, USA, 2009.

85. Hwang, M.; Lee, Y.; Choi, K.; Park, C. Urinary 3-Phenoxybenzoic Acid Levels and the Association with Thyroid Hormones in Adults: Korean National Environmental Health Survey 2012-2014. Sci. Total Environ. 2019, 696, 133920. [CrossRef] 
86. Morgan, M.; Jones, P.; Sobus, J.; Boyd Barr, D. Predictors of Urinary 3-Phenoxybenzoic Acid Levels in 50 North Carolina Adults. Environ. Res. Public Health 2016, 13, 1172. [CrossRef]

87. Park, S.H. Factors Affecting Cigarette Use and an Increase in Smoking Frequency among Adolescents in South Korea. Korean J Child Health Nurs. 2007, 13, 318-328.

88. Stiby, A.I.; Macleod, J.; Hickman, M.; Yip, V.L.; Timpson, N.J.; Munafò, M.R. Association of Maternal Smoking with Child Cotinine Levels. Nicotine Tob. Res. 2013, 15, 2029-2036. [CrossRef] [PubMed]

89. Fernández, S.F.; Pardo, O.; Hernández, C.S.; Garlito, B.; Yusà, V. Children's Exposure to Polycyclic Aromatic Hydrocarbons in the Valencian Region (Spain): Urinary Levels, Predictors of Exposure and Risk Assessment. Environ. Int. 2021, 153, 106535. [CrossRef] [PubMed]

90. Huang, X.; Deng, X.; Li, W.; Liu, S.; Chen, Y.; Yang, B.; Liu, Q. Internal Exposure Levels of Polycyclic Aromatic Hydrocarbons in Children and Adolescents: A Systematic Review and Meta-Analysis. Environ. Health Prev. Med. 2019, 24, 50. [CrossRef]

91. Murawski, A.; Roth, A.; Schwedler, G.; Schmied-Tobies, M.I.H.; Rucic, E.; Pluym, N.; Scherer, M.; Scherer, G.; Conrad, A.; Kolossa-Gehring, M. Polycyclic Aromatic Hydrocarbons (PAH) in Urine of Children and Adolescents in Germany-Human Biomonitoring Results of the German Environmental Survey 2014-2017 (GerES V). Int. J. Hyg. Environ. Health 2020, $226,113491$. [CrossRef]

92. Abdel-Shafy, H.I.; Mansour, M.S.M. A Review on Polycyclic Aromatic Hydrocarbons: Source, Environmental Impact, Effect on Human Health and Remediation. Egypt. J. Petrol. 2016, 25, 107-123. [CrossRef]

93. Wilhelm, M.; Hardt, J.; Schulz, C.; Angerer, J.; Human Biomonitoring Commission of the German Federal Environment Agency. New Reference Value and the Background Exposure for the PAH metabolites 1-Hydroxypyrene and 1- and 2-Naphthol in Urine of the General Population in Germany: Basis for Validation of Human Biomonitoring Data in Environmental Medicine. Int. J. Hyg. Environ. Health 2008, 211, 447-453. [CrossRef]

94. Fernández, S.F.; Pardo, O.; Pastor, A.; Yusà, V.; Vento, M.; Cernada, M.; Gormaz, M.; Kuligowski, J.; Sánchez, A.; Torres, E.; et al. Biomonitoring of Polycyclic Aromatic Hydrocarbons in the Urine of Lactating Mothers: Urinary Levels, Association with Lifestyle Factors, and Risk Assessment. Environ. Pollut. 2021, 268, 115646. [CrossRef]

95. Kwon, Y.M.; Joo, Y.; Park, C.H.; Kim, S.Y.; Choi, K.; Lee, C.; Yu, S.D.; Yoo, J. Exposure Levels and Influence Factors of PAHs and Benzene Metabolites in the Urine of the General Korean Adult Population-Korean National Environmental Health Survey (2009-2017). Int. J. Hyg. Environ. Health 2019, 45, 529-540. [CrossRef]

96. Schulz, C.; Angerer, J.; Ewers, U.; Heudorf, U.; Wilhelm, M.; Human Biomonitoring Commission of the German Federal Environment Agency. Revised and New Reference Values for Environmental Pollutants in Urine or Blood of Children in Germany Derived from the German Environmental Survey on Children 2003-2006 (GerES IV). Int. J. Hyg. Environ. Health 2009, 212, 637-647. [CrossRef] [PubMed]

97. Jalai, A.; Ramezani, Z.; Ebrahim, K. Urinary Trans, Trans-Muconic Acid Is Not a Reliable Biomarker for Low-Level Environmental and Occupational Benzene Exposures. Saf. Health Work 2017, 8, 220-225. [CrossRef] [PubMed]

98. Jain, R.B. Levels of selected urinary metabolites of volatile organic compounds among children aged 6-11 years. Environ. Res. 2015, 142, 461-470. [CrossRef] [PubMed]

99. Quirós-Alcalá, L.; Wilson, S.; Witherspoon, N.; Murray, R.; Perodin, J.; Trousdale, K.; Raspanti, G.; Sapkota, A. Volatile Organic Compounds and Particulate Matter in Child Care Facilities in the District of Columbia: Results from a Pilot Study. Environ. Res. 2016, 146, 116-124. [CrossRef] 